\title{
RAF expression in human astrocytic tumors
}

\author{
CARSTEN HAGEMANN ${ }^{1}$, JENS GLOGER ${ }^{1}$, JELENA ANACKER ${ }^{2}$, HARUN M. SAID ${ }^{3}$, STEFANIE GERNGRAS ${ }^{1}$, \\ SIGLINDE KÜHNEL ${ }^{1}$, CHRISTOPH MEYER ${ }^{4}$, ULF RÜDIGER RAPP ${ }^{5}$, ULRIKE KÄMMERER ${ }^{2}$, \\ DIRK VORDERMARK ${ }^{3}$, MICHAEL FLENTJE $^{3}$, KLAUS ROOSEN $^{1}$ and GILES HAMILTON VINCE ${ }^{1}$ \\ ${ }^{1}$ Department of Neurosurgery, Tumorbiology Laboratory, University of Würzburg, Josef-Schneider-Str. 11; \\ Departments of ${ }^{2}$ Obstetrics and Gynaecology, ${ }^{3}$ Radiation Oncology, University of Würzburg, Josef-Schneider-Str. 4, \\ D-97080 Würzburg; ${ }^{4}$ Department of Medicine II, Molecular Alcohol Research in Gastroenterology, Faculty of Medicine \\ at Mannheim, University of Heidelberg, Theodor-Kutzer-Ufer 1-3, D-68167 Mannheim; ${ }^{5}$ Institut für Medizinische \\ Strahlenkunde und Zellforschung (MSZ), University of Würzburg, Versbacher Str. 5, D-97078 Würzburg, Germany
}

Received August 29, 2008; Accepted October 6, 2008

\section{DOI: 10.3892/ijmm_00000097}

\begin{abstract}
RAF proteins are well known oncoproteins. The B-RAF has been shown to be activated by mutations in a multitude of human cancers. Alterations of C-RAF expression are discussed to play a role in lung cancer. Only for A-RAF no link to tumorigenesis has been published so far. Malignant gliomas are the most prevalent primary brain tumors of adults. They are highly invasive and very difficult to treat, despite of surgery, $\gamma$-irradiation and chemotherapy. Although a role of the mitogenic Ras-RAF-MEK-ERK signalling cascade in brain tumor development is well established, there are only few reports available addressing alterations in RAF sequence or protein expression and function in human gliomas. We analysed the mutational status of A-RAF and B-RAF in human glioblastomas (GBM) by sequencing. Then we checked for RAF gene amplification by dot blot hybridization and examined RAF mRNA and protein expression patterns in human astrocytic gliomas of WHO grade II (LGA) and IV (GBM) by semiquantitative RT-PCR and Western blotting, respectively. The results were correlated with patients prognosis. Finally, we performed functional assays to address a putative function of A-RAF in glioma cell proliferation and migration. We showed that RAF mutations are a rare event in glioblastoma multiforme. A-raf gene amplification was more often detected and overexpression of all three RAF proteins on mRNA and protein level was regularly found in human malignant gliomas. Whereas A-RAF and C-RAF expression
\end{abstract}

Correspondence to: Dr C. Hagemann, Department of Neurosurgery, Tumorbiology Laboratory, University of Würzburg, JosefSchneider-Str. 11, D-97080 Würzburg, Germany

E-mail: hagemann_c@klinik.uni-wuerzburg.de

Key words: A-RAF, astrocytoma, B-RAF, C-RAF, expression analysis, glioblastoma multiforme, glioma, sequencing was negatively correlated with the patients prognosis, B-RAF expression had a positive effect. Since neither A-RAF, nor $\mathrm{C}-\mathrm{RAF}$ expression had any influence on proliferation and migration of GBM cells, putative functions of C-RAF in angiogenesis and of A-RAF in regulation of metabolism are discussed. Our data indicate that RAF proteins might be valuable targets for small molecule therapies. However, initially specific functions of RAF during tumorigenesis have to be elucidated.

\section{Introduction}

Diffuse astrocytomas WHO grade II (low grade astrocytomas, LGA) are well differentiated tumors with diffuse infiltration of the adjacent brain parenchyma (1). Despite their relatively slow growth, this infiltrating behavior is one reason for a median survival of patients in the range of only 5 years after diagnosis $(2,3)$. In addition, most of these tumors progress to anaplastic astrocytomas WHO grade III or glioblastoma multiforme (GBM) within 4-5 years after diagnosis (4). GBM are the most prevalent, highly malignant, invasive and difficult to treat primary brain tumors of adults. This tumor can either develop by progression from less malignant gliomas or de novo without any precursor lesion (1). Treatment regimen of patients with GBM include neurosurgical tumor resection followed by local $\gamma$-irradiation and chemotherapy (1). However, in spite of such multi-disciplinary treatment the median survival is $<14$ months (5).

Nowadays, more targeted therapies based on small molecules are in development. These therapies aim to block signalling pathways, which are specifically altered during progression of astrocytic gliomas (6). Already in early stages there are gains of chromosome 7 or $7 \mathrm{q}$ in $>50 \%$ of all LGA $(7,8)$. About $60 \%$ of these tumors carry mutations in the p53 tumor suppressor gene, accompanied by loss of heterozygosity (LOH) on chromosome $17 \mathrm{p}(9,10)$. This results in complete absence of wild-type p53. Frequently, elevated expression of the platelet-derived growth factor receptor $\alpha$ (PDGFRA) and the corresponding ligand PDGF $\alpha$ are observed, arguing for a growth stimulating autocrine loop $(11,12)$. This leads to activation of mitogenic signalling pathways, such as the 
mitogen-activated protein kinase (MAPK) cascade. In anaplastic astrocytoma WHO grade III mutations in cell cycle regulatory genes, like e.g., CDKN2A, CDKN2B, pRb1, CDK4, CDK6, CCND1 or CCND3, are seen in addition to the above-mentioned alterations (1). GBM additionally demonstrate deletion of chromosome 10 and alteration of the phosphoinositide 3-kinase (PI3K)/protein kinase B (Akt) signalling pathway (1). In about $60 \%$ of cases there is overexpression and in $\sim 40 \%$ amplification of the epidermal growth factor receptor (EGFR) gene (6). Therefore, recent developments in small-molecule therapies aim to target these receptors and their downstream signalling pathways. Gefitinib (Iressa ${ }^{\circledR}$; Astra Zeneca Pharmaceuticals, Wilmington, DE) and Erlotinib (Tarceva ${ }^{\circledR}$; OSI Pharmaceuticals, Inc., Melville, NY) are two examples for targeted drugs directed against EGFR activity and Imatinib mesylate (Gleevec ${ }^{\circledR}$; Norvartis Pharmaceuticals Corp.) has inhibitory effects on the PDGFR. All these drugs are currently in phase II studies (6).

These tyrosine kinase receptors have in common that they stimulate the mitogenic Ras-RAF-MEK-ERK signalling cascade. Human malignant astrocytomas frequently display the active GTP bound form of Ras, and thereby proliferation of these cells is increased (13). Co-expression of active Akt and oncogenic H-Ras in neuronal progenitor cells (14) and specific expression of oncogenic H-Ras under control of the glial fibrillary acidic protein (GFAP) promoter in astrocytes (15), respectively, causes GBM formation with the histological features of human GBM in mouse models. Ras proteins belong to the group of small G-proteins and convey receptor signalling to the cytoplasmic RAF protein serine/threonine kinases which then signal through MEK and ERK to regulate a wide range of cellular functions, including protein synthesis, transcription, angiogenesis, cell cycle, cell proliferation and cell survival (16-18). Three RAF proteins are known: A-RAF, B-RAF and C-RAF. Whereas there is no evidence yet that A-RAF may be involved in tumor progression (19-21), a role for mutated and activated B-RAF, especially B-RAF V600E (formerly described as B-RAF V599E) (22), in melanomas and in ovarian, thyroid and colorectal carcinomas is well established $(21,23,24)$. A putative role for C-RAF in lung cancer development is discussed $(18,25,26)$. Treatment of the U87MG glioblastoma cell line with the C-RAF inhibitor GW5074 in combination with blockage of the PI3K/Akt pathway leads to a synergistic reduction of colony formation in soft agar (27) and AAL881, a new small-molecule inhibitor of B-RAF, C-RAF and vascular endothelial growth factor receptor 2 (VEGFR2) kinase activities, leads to cell cycle arrest, inhibition of both motility and invasion of GBM cells and induces regression of orthotope glioma xenografts in mice (28). These results indicate that RAF mediated pathways may also be of importance for GBM progression and that inhibition of such pathways may be of therapeutic relevance.

Although there are only few reports available addressing alterations in RAF sequence $(29,30)$ or protein expression and function in human gliomas $(31,32)$, there is evidence that the mitogenic MAPK cascade is functionally important in glioma proliferation $(14,15,27,28)$. Therefore, we analysed RAF protein sequences and expression patterns in human astrocytic gliomas of WHO grade II and IV and examined putative functions of RAF proteins in glioma cell proliferation and migration.

\section{Materials and methods}

Tissue samples. Informed consent of the patient was obtained for the acquisition of tumor material as approved by the local ethics committee. All tissue samples were obtained from patients treated in the University Hospital Würzburg. The patients underwent surgical tumor resection followed by radiotherapy and Temozolomide chemotherapy. However, two glioblastoma multiforme WHO grade IV (GBM) samples (2369 and 2423) were from recurrent tumors pretreated with $\gamma$-irradiation and chemotherapy. Expression of RAF was analysed using three samples of temporal brain tissue (normal brain, NB), derived from patients with epilepsy (kindly provided by Thomas Freiman, University Hospital Freiburg im Breisgau, Germany), 15 low grade astrocytomas WHO grade II (LGA) and 15 GBM. Details about patient's sex, age, diagnosis, location of tumor and treatment regimen for these samples have been described previously (33).

Immediately after surgery tissue samples were frozen at $-80^{\circ} \mathrm{C}$ and then stored in liquid nitrogen. The classification of human brain tumors used in this study was determined by routine histology based on criteria of the World Health Organisation (34).

Cells, cell culture and cell transfection. Human GBM cell lines U87, U251 and U373 were purchased from ATCC (American Type Culture Collection, Rockville, MD), and GaMG was established from a patient with glioblastoma multiforme (Gade Institut of the University Bergen, Norway) (35). Cells were grown under the conditions reported elsewhere (36) in $75 \mathrm{~cm}^{2}$ flasks (Corning, New York, USA) at $37^{\circ} \mathrm{C}, 5.0 \% \mathrm{CO}_{2}$ and $100 \%$ humidity.

Cells were passaged two days prior to transfection by nucleofection (Amaxa, Cologne, Germany) and grown to $80 \%$ confluency. Subsequently, cells were trypsinised $(0.25 \%$ Trypsin-EDTA; Invitrogen, Heidelberg, Germany), washed with phosphate-buffered saline (PBS) and for each transfection $1 \times 10^{6}$ cells were resuspended in $100 \mu 1$ nucleofector solution V (Amaxa). Of each plasmid $2 \mu \mathrm{g}$ (pCMV5; pCMV5-A-RAF) was added and nucleofected using programme T-20 (36). The same conditions were used for siRNA transfection. The sequences of the control siRNA scrambled and the siRNA targeting A-RAF have already been published $(36,37)$. They were synthesized by Qiagen (Hilden, Germany). In total, $3 \mu \mathrm{g}$ siRNA were used per transfection. Transfected cells were transferred to 6-well plates and incubated for $24 \mathrm{~h}$ or more, as described. The generation of spheroids, which were used for migration assays, is described elsewhere (36).

Isolation of genomic DNA, RNA and protein. Genomic DNA was isolated from 10-20 mg tissue samples and $3 \mathrm{ml}$ frozen blood samples, respectively, using the wizard genomic DNA purification kit (Promega, Heidelberg, Germany) according to the manufacturer's manual. Isolated DNA was dissolved in $100 \mu 1$ (tissue) or $250 \mu 1$ (blood) rehydration buffer and stored at $-20^{\circ} \mathrm{C}$. 


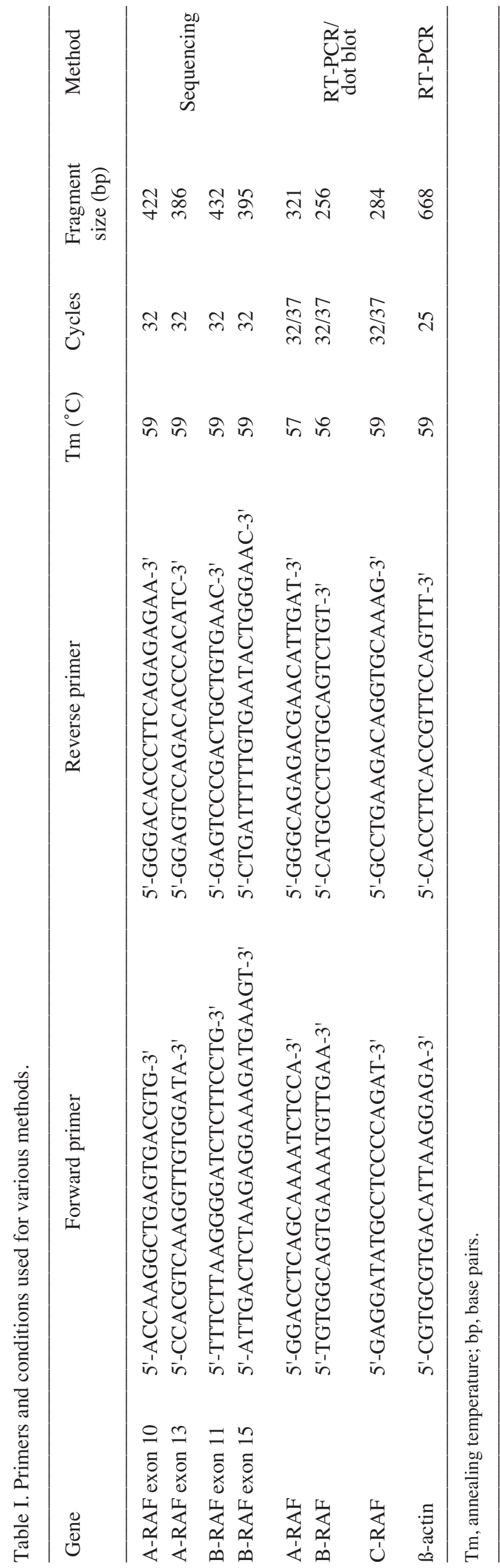

Trypsinised cells were washed twice with PBS and then resuspended in $50 \mu 1 \mathrm{PBS}$. Total mRNA and protein was purified from these cells and from $30 \mathrm{mg}$ of surgical specimens, respectively, by the Nucleo-Spin RNA/Protein Kit (MachereyNagel, Düren, Germany) according to the manufacturer's instructions. During extraction RNA was treated with RNasefree DNase I to eliminate DNA contaminations in the samples, as recommended by the manufacturer. The RNA samples were eluted with $60 \mu 1$ RNase-free water and proteins were solubilized in $100 \mu 1$ protein loading buffer (PLB) containing $50 \mathrm{mM}$ Tris (2-carboxyethyl) phosphine hydrochloride (TCEP) reducing agent. Purified RNA samples were stored at $-80^{\circ} \mathrm{C}$ and protein/PLB-TCEP mixtures at $-20^{\circ} \mathrm{C}$.

For Western blot detection of proteins after transfection and protein knock-down in spheroids, spheroids not used for migration assays were sedimented and solubilized with $50 \mu 1$ lysis buffer (10 mM Tris-Cl pH 7.4, $150 \mathrm{mM} \mathrm{NaCl}, 1 \mathrm{mM}$ EDTA, 1 mM EGTA, $1 \%(\mathrm{v} / \mathrm{v})$ Triton X-100, 0.5\% (v/v) IGEPAL CA-630, $1 \mathrm{mM}$ PMSF, $10 \mu \mathrm{g} / \mathrm{ml}$ leupeptin, $23 \mu \mathrm{g} / \mathrm{ml}$ aprotinin). Cells from monolayer cultures (proliferation assay) were solubilized in a concentration of 17,000 cells $/ \mu 1$ lysis buffer. Of each lysate $32.5 \mu \mathrm{l}$ was mixed with $5 \mu \mathrm{l}$ NuPage Sample Reducing Agent and 12.5 $\mu$ LDS sample buffer (both from Invitrogen). All protein lysates were stored at $-20^{\circ} \mathrm{C}$.

DNA sequencing. A-raf exons 10 and 13 and $B$-raf exons 11 and 15 were amplified by polymerase chain reaction (PCR) from genomic DNA using primers and conditions shown in Table I. PCR products were sequenced using BigDye Terminator Cycle Sequencing Ready Reaction Kit (Applied Biosystems, Foster City, CA, USA) according to the manufacturer's manual, and analyzed on an ABI PRISM 3100 Avant Genetic Analyzer. The sequences were first analyzed by visual inspection, looking for double peaks or untypical background signals. Additional alignments with the published genomic sequence were performed using the multiple sequence alignment software MAFFT version 6 (38) and box-shades for better visual analysis were generated online using BOXSHADE 3.21 (39).

Southern blotting. Probes directed against genomic DNA sequences of the three raf-genes were generated by PCR using primers shown in Table I. The PCR was performed using $2.5 \mathrm{U}$ Taq polymerase in each $25 \mu 1$ reaction, containing $10 \mathrm{X}$ buffer with $1.5 \mathrm{mM} \mathrm{MgCl}_{2}$ (Eppendorf, Hamburg, Germany). Thermocycle parameters were as follows: $5 \mathrm{~min}$ at $94^{\circ} \mathrm{C} ; 37$ cycles of $30 \mathrm{sec}$ at $94^{\circ} \mathrm{C}, 30 \mathrm{sec}$ at the respective annealing temperature (Table I), $30 \mathrm{sec}$ at $72^{\circ} \mathrm{C}$; and $10 \mathrm{~min}$ at $72^{\circ} \mathrm{C}$. PCR products were dissolved in $15 \mu \mathrm{l} \mathrm{H}_{2} \mathrm{O}$ and denatured for $10 \mathrm{~min}$ at $95^{\circ} \mathrm{C}$. After cooling down on ice, DIG-dNTP labelling was performed by adding $2 \mu \mathrm{l}$ hexanucleotide mixture (Roche Applied Science, Mannheim, Germany), $2 \mu 1$ DIG-dNTPs (Roche Applied Science) and 10 U Klenow fragment (MBI Fermentas, Burlington, Canada). After 60 -min incubation at $37^{\circ} \mathrm{C}$ the reaction was stopped by adding $2 \mu \mathrm{l}$ of a $0.2 \mathrm{M}$ EDTA solution $\mathrm{pH}$ 8.0. The DNAprobes were precipitated by adding $2.5 \mu \mathrm{l}$ of a $3 \mathrm{M} \mathrm{Na}-$ acetate solution $\mathrm{pH} 4.5$ and $75 \mu 1$ ethanol. After 30-min incubation at $-70^{\circ} \mathrm{C}$ DNA was sedimented by $30-\mathrm{min}$ 
centrifugation at $13,000 \mathrm{x} \mathrm{g}, 4^{\circ} \mathrm{C}$. The pellet was washed once with $70 \%$ ethanol, dried in a speed-vac and dissolved in $50 \mu 1$ TE buffer (10 mM Tris, 1 mM EDTA, pH 8.0).

Genomic DNA was isolated as described above and $10 \mu \mathrm{g}$ of each sample was applied to a positively charged nylon membrane (Schleicher \& Schüll, Dassel, Germany) for dot hybridization. The dots were dried and crosslinked under UV radiation descending from 120,000 to $0 \mu \mathrm{J}$. Hybridization was performed according to the manual of the DIG Luminescent Detection Kit (Roche Applied Science), except that incubation took place in $100 \mathrm{ml}$ antibody solution, equilibration in $100 \mathrm{ml}$ detection buffer and development in $50 \mathrm{ml}$ of a 1:100 dilution of CSPD in detection buffer.

Semiquantitative RT-PCR analysis. Expression of RAF mRNA was analysed by semiquantitative RT-PCR following a standard protocol $(33,40)$. The amount of cDNA was normalized to the amount of the housekeeping gene $\beta$-actin. cDNA amplification and expression analysis was performed using primers given in Table I. These primers were designed in flanking exons with Primer3 software (41). PCR conditions were as described above for Southern blot probe generation, except that cycles given in Table I were used. These PCR conditions were optimized for each primer-pair. The amplification products were separated on $1 \%$ agarose gels (Sigma, Deisenhofen, Germany) containing $0.07 \mu \mathrm{g} / \mathrm{ml}$ ethidiumbromide (Roth, Karlsruhe, Germany).

Western blotting. Expression of RAF proteins was determined by Western blotting. In total, 3-10 $\mu 1$ of the protein/PLB-TCEP mixture, $25 \mu \mathrm{l}$ of spheroid lysates and $20 \mu \mathrm{l}$ of monolayer lysates per lane were separated on NuPage ${ }^{\circledR} 3-8 \%$ Tris-acetate polyacrylamide gels (Invitrogen) and transferred to nitrocellulose membranes (Schleicher \& Schüll). After blocking in $5 \%$ milk powder, the membranes were incubated with rabbit polyclonal anti-Raf antibodies (Raf-A, Raf-B, Raf-1; Santa Cruz, CA, USA) which are directed against C-terminal epitopes, diluted 1:250 in TBST (50 mM Tris Base, $150 \mathrm{mM}$ $\mathrm{NaCl}, 0.1 \%$ (v/v) Tween-20) containing 5\% milk powder. Rabbit polyclonal anti-GAPDH (Abcam, Cambridge, UK) antibody was diluted 1:1000, mouse monoclonal anti- $\gamma$-tubulin primary antibody (Sigma) was used at a dilution of 1:5000 and mouse monoclonal anti- $\beta$-actin antibody (Sigma) was diluted 1:10000 in TBST. After washing in TBST, the membrane was incubated with horseradish peroxidase (HRP) conjugated secondary antibodies: goat anti-rabbit IgG HRP (Santa Cruz, CA, USA) or sheep anti-mouse IgG HRP (Amersham Pharmacia Biotech, Braunschweig, Germany), both diluted 1:1000 in TBST. Blots were developed in the darkroom using the ECL-immunodetection system (Amersham Pharmacia Biotech).

Immunohistochemistry. GBM sections $(2 \mu \mathrm{m})$ were cut from formalin-fixed, paraffin-embedded tissue blocks and stained as described in $(33,40)$ using the same primary polyclonal RAF antibodies as mentioned above for Western blotting in a dilution of 1:250. RAF protein expression was visualized using the streptavidin-biotin system (Dako, Hamburg, Germany) and diaminobenzidine (DAB; Sigma) as a substrate, which resulted in brown staining $(33,40)$. The slides were counterstained with haematoxylin and analysed using a light microscope BX41 (Olympus, New York, USA). Negative control experiments were carried out by staining with appropriate isotype control antibodies.

Migration assay. Spheroids of equal size (200 $\mu \mathrm{m}$ in diameter) were transferred to 96 -well plates $48 \mathrm{~h}$ after transfection. The wells were coated with $0.01 \%$ poly-D-lysine (Sigma) and single tumor spheroids were placed in the middle of each well. The area covered by the spheroid and by cells spreading out from the spheroid was documented $0,12,24,36$ and $46 \mathrm{~h}$ after placing the spheroids. This migration area was morphometrically assessed in percent of the original spheroid radius using a stereomicroscope and a non-commercial specialized software (42). The experiment was performed with a minimum number of 5 spheroids per transfection (Table IV).

Proliferation assay. Cells were transfected as described above. Cells $\left(2 \times 10^{6}\right)$ were seeded on $60 \mathrm{~mm}$ Petri-dishes (Corning, New York, USA) after transfection and given $24 \mathrm{~h}$ to recover from the transfection procedure. After that, cells were trypsinised and $5 \times 10^{4}$ cells were seeded in $60 \mathrm{~mm}$ Petri-dishes, filled with $3 \mathrm{ml}$ medium, each. Cells were then harvested at 24-h intervals over a period of 7 days by trypsinisation and counted using a Fuchs-Rosenthal chamber. The fold increase in cell number compared to day 3 after transfection was calculated to establish growth curves. Experiments were run in triplicate.

Statistical analysis. The intensity of the DNA and protein bands was quantified by densitometry using the BioDocAnalyze software (Biometra, Göttingen, Germany) and the DNA and protein bands were normalized with respect to $B$-actin and $\gamma$-tubulin, respectively. Statistical analysis was performed using Microsoft Office Excel 2003 (Microsoft Deutschland $\mathrm{GmbH}$, Unterschleissheim, Germany). Values were expressed as means \pm standard error of the mean. Statistical significance was defined by two tailed t-tests and $\mathrm{p}<0.05$ was considered to be significant. Box-Plots were generated using GraphPad Prism 4 Software (GraphPad Software Inc., San Diego, USA) and statistical significance was determined by analysis of variance (ANOVA).

\section{Results}

Activating mutations of $R A F$ proteins are rare in human astrocytic tumors. B-RAF was found activated by mutations in a multitude of human cancers with highest incidence in malignant melanoma $(21,23,24)$. These hot-spot mutations concentrate in exons 11 and 15 of $B$-raf $(23,24)$. For A-RAF a comparable sequence analysis is only available for ovarian epithelial tumors, gastric adenocarcinomas, acute leukemias and colorectal carcinomas, without any mutations detected $(20,43)$. Therefore, we amplified the coding sequences of $A$-raf exon 10 and $A$-raf exon 13 from 66 and 63 GBM samples, respectively, by PCR and subjected them to sequence analysis (Table II). These exons correspond to the above-mentioned $B$-raf exons. However, no nucleotide exchange which would alter the amino acid sequence of the A-RAF protein was detected. In one case, a single nucleotide polymorphism was 
Table II. RAF-sequence alterations in glioblastoma multiforme (GBM).

\begin{tabular}{lccc}
\hline & GBM samples analysed & Mutation & No. of samples with mutations \\
\hline A-RAF exon 10 & 66 & C1001T $\rightarrow$ A334A & 1 \\
A-RAF exon 13 & 63 & - & 0 \\
B-RAF exon 11 & 74 & - & 0 \\
B-RAF exon 15 & 44 & T1799A $\rightarrow$ V600E & 1 \\
\hline
\end{tabular}

Table III. Median survival time (weeks) of patients with strong and weak expression of RAF mRNA and protein.

\begin{tabular}{|c|c|c|c|c|c|c|c|}
\hline & \multicolumn{3}{|c|}{ mRNA } & \multicolumn{4}{|c|}{ Protein } \\
\hline & $\mathrm{A}-\mathrm{RAF}^{\mathrm{a}}$ & B-RAF & C-RAF & A-RAF & $\begin{array}{l}\text { B-RAF } \\
95 \mathrm{kDa}\end{array}$ & $\begin{array}{l}\text { B-RAF } \\
68 \mathrm{kDa}\end{array}$ & C-RAF \\
\hline Strong expression & 21.6 & 86.4 & 97.3 & 24.9 & 32.9 & 100.1 & 18.7 \\
\hline Weak expression & 64.7 & 19.6 & n.a. & 29.4 & 29.3 & 19.6 & 29.4 \\
\hline Difference & -43.1 & +66.8 & & -4.5 & +3.6 & +80.5 & -10.7 \\
\hline
\end{tabular}

aStrong vs. no expression. n.a., not applicable.

found in A-raf exon 10, where the cytosine at position 1001 was replaced by a thymidine (Fig. 1a). The absence of a double peak at this position indicates that it is a homozygous polymorphism. In addition, this was not a tumor specific alteration, because the same exchange was detected in peripheral blood leukocytes of the patient (Fig. 1a).

$B$-raf exon 11 and $B$-raf exon 15 were also analysed in 74 and 44 GBM biopsies, respectively (Table II). No nucleotide exchange was detected in $B$-raf exon 11 . However, the tumor of one patient harboured the hot-spot mutation T1799A leading to the activating amino acid exchange V600E (Fig. 1b). This GBM-patient was progression-free for 5 years after initial surgery and chemotherapy, before recurrent disease appeared. In this recurrent GBM tissue the same B-RAF T1799A mutation was found (Fig. 1b). The double peak in the sequence at this position indicates that the mutation was heterozygous (Fig. 1b). In addition, this sequence alteration was tumor specific, since analysis of a peripheral blood sample from the patient revealed a wild-type $B$-raf sequence (Fig. 1b).

A-RAF but not B-RAF or C-RAF shows allelic gains in human astrocytic tumors. The fact that activating RAF mutations only occur in about $2 \%$ of the analysed GBM does not necessarily mean that RAF proteins are not involved in brain tumor development. Therefore, we checked for amplification of the different raf genes by dot blot hybridization. Equal amounts of genomic DNA from 15 low grade astrocytoma (WHO grade II, LGA) and 15 GBM were dotted onto a membrane and hybridized with RAF isoform specific probes. Patient gender was evenly distributed in the two groups of LGA and GBM (33). We got strong signals suggesting amplification of the A-raf gene in at least one of the LGA (tumor 2201) and one of the GBM (tumor 2414) (Fig. 2).

RAF mRNA expression is increased in human astrocytic tumors in comparison to normal tissue. To confirm overexpression of A-RAF by these tumors, we analysed mRNA expression of the three RAF isoforms in the above-mentioned panel of 15 LGA and 15 GBM by semiquantitative RT-PCR (Fig. 3). In addition, three normal brain tissues (NB) were screened. Compared to these NB samples, tumors 2201 and 2414 showed increased expression of A-RAF mRNA, whereas they did not display a major change in the expression strength of B-RAF or C-RAF mRNA (Fig. 3). Generally, expression of the three RAF family members was detectable in nearly all samples analysed. Only A-RAF was not demonstrable in some LGA and GBM samples (Figs. 3a and 6a). Whereas B-RAF and C-RAF showed a nearly homogeneous distribution, A-RAF displayed a high diversity in expression strength between the different glioma samples (Fig. 3a). Densitometric quantification was performed on a scale from 0 to 100 (zero meaning no expression detectable, 100 representing the strongest RAF expression within the panel: C-RAF expression of tumor 2329). Each value was normalized to the corresponding expression of the housekeeping gene $\beta$-actin and results were presented in form of box-plots. This analysis revealed that there was a successive increase of A-RAF mRNA expression from NB via LGA to GBM (Fig. 3b). The fluctuation range of B-RAF and C-RAF mRNA expression was increased in tumor tissue compared to NB (Fig. 3c and d). Although there was no difference between the maximum and minimum relative expression values of B-RAF mRNA in LGA compared to GBM, the 
a)

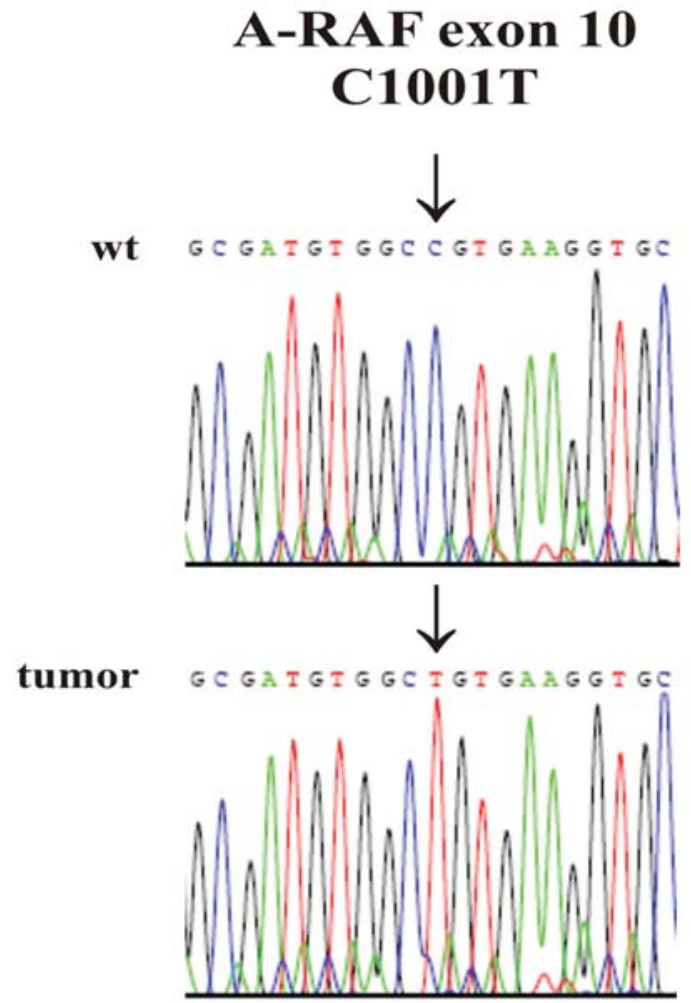

\section{relapse}
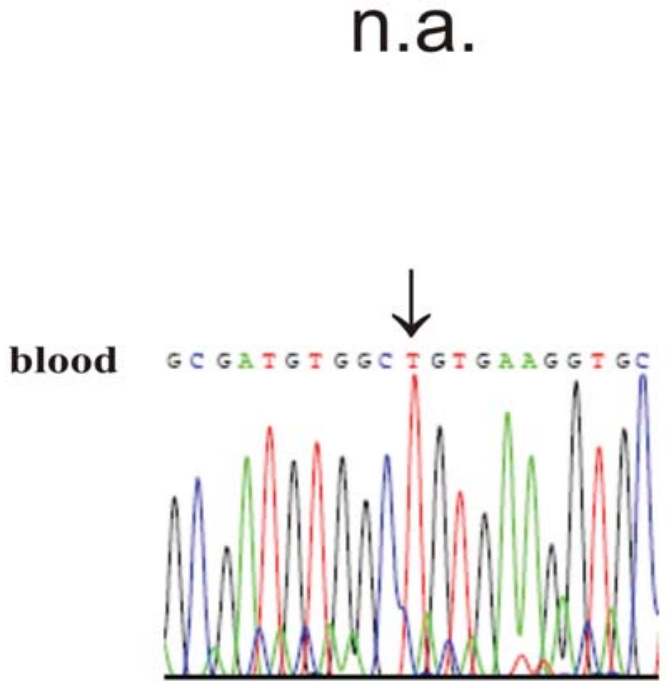

b)

\section{B-RAF exon 15 T1799A}

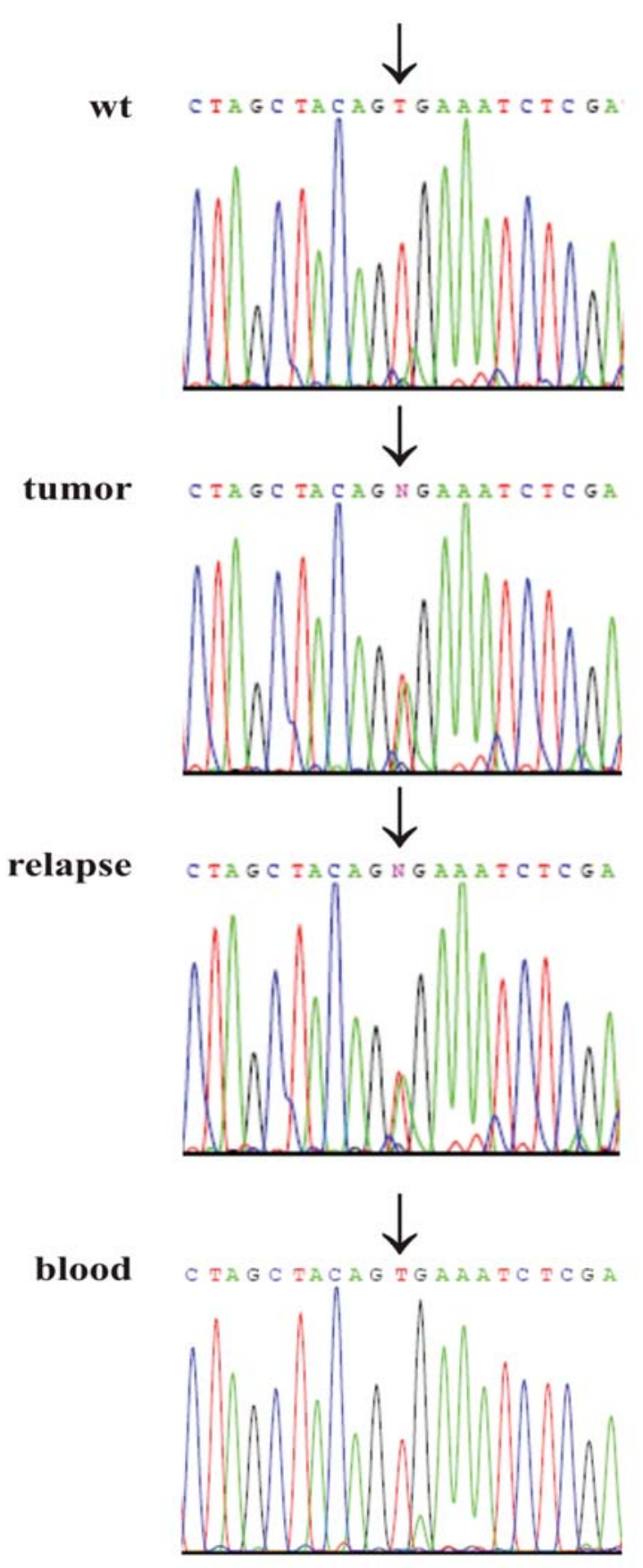

Figure 1. Sequence alterations of patients with glioblastoma multiforme. (a) Homozygous polymorphism of $A$-raf exon 10 leading to C1001T exchange. (b) Heterozygous B-raf exon 15 T1799A mutation leading to V600E amino acid exchange on protein level. Arrows indicate the base of interest. wt, wild-type sequence. Tumor, sequence found in the initial tumor. Relapse, sequence seen in recurrent disease. Blood, sequence detected in blood cells of the respective patient. n.a., not available.

median relative expression of B-RAF mRNA was reduced from 60.3 and 57.5 in NB and LGA, respectively, to 44.9 in GBM (Fig. 3c). In contrast, C-RAF mRNA expression was increased in GBM compared to LGA (Fig. 3d).

These alterations in RAF mRNA expression were reflected by the number of tumors in the sample set showing no, weak
( $>0$ but $<50$ on the above described scale) or strong $(\geq 50)$ RAF mRNA signals (Fig. 6a). B-RAF and C-RAF were expressed by all samples analysed (Fig. 6a). Whereas there was no change in the percentage of tumors with strong $\mathrm{C}$ RAF expression (100\% NB, 93\% LGA, 100\% GBM), strong B-RAF expression was reduced from $67 \%$ of NB and $67 \%$ 
LGA

GBM

\begin{tabular}{|c|c|c|c|c|c|c|c|c|c|c|c|c|c|c|c|c|c|c|c|c|c|c|c|c|c|c|c|c|c|c|}
\hline & $\stackrel{\infty}{\sim}$ & $\underset{\widetilde{\Xi}}{\widetilde{\Xi}}$ & 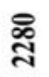 & $\stackrel{\mathscr{\sim}}{\approx}$ & స్లై & 竎 & 음 & $\stackrel{\mathscr{d}}{\mathscr{d}}$ & $\stackrel{\infty}{\approx}$ & ฮై & สิ & స్త & 룽 & గ్రి & $\stackrel{3}{3}$ & త్ర & సิ సે & స్తి & $\underset{d}{\mathbb{N}}$ & 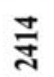 & 志 & 胥 & ন্ & สั & 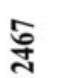 & 高 & 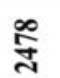 & 呑 & 总 & है \\
\hline$A-r a f$ & 0 & 0 & 0 & 0 & $\circ$ & - & 0 & - & 0 & $\bullet$ & 0 & & 0 & 0 & 。 & 0 & 0 & 0 & 0 & 0 & 0 & 0 & n & 。 & 0 & 。 & 。 & 。 & 。 & 。 \\
\hline$-r a f$ & 8 & 6 & .0 & & 0 & e & 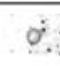 & & $8:$ & $\theta:$ & 0. & 0 & 0 & $\dot{\gamma}$ & 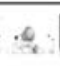 & & $\therefore$ & 0 . & & 0. & 0 & $\therefore$ & 4 & is: & 0 & 0 & $\therefore$ & & & 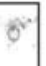 \\
\hline$C-r a f$ & 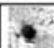 & - & 0 & 2 & $0: 5$ & 0 & $\therefore 8$ & 0 & 8 & 0 & $0^{\circ}$ & to & 0 & 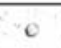 & 0 & $6^{2}$ & a. & 0 & $x$ & 0 & 0 & - & Q9. & 8. & 0 & 0 & $\bullet$ & 0 & 0 & e \\
\hline
\end{tabular}

Figure 2. Southern dot blot analysis of raf genomic DNA content in 15 LGA and 15 GBM. Genomic DNA was isolated from tumor biopsies and $10 \mu \mathrm{g}$ DNA of each sample dot blotted onto a positivly charged nylon membrane. RAF-isoform specific probes were DIG-dNTP labelled and luminescence was detected. Boxes indicate tumor samples with amplified $A$-raf gene compared to $B$-raf and $C$-raf.

a)

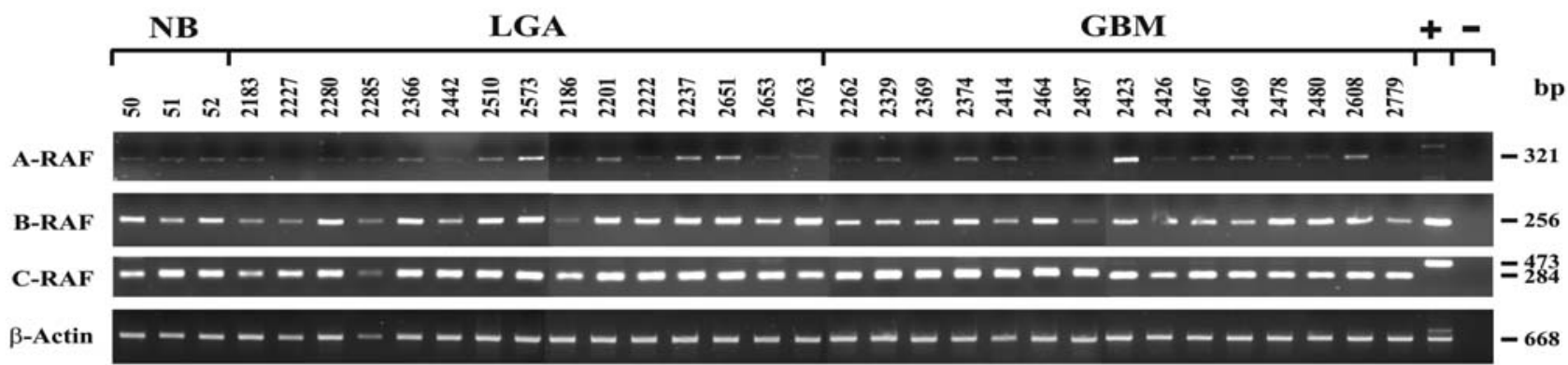

b)

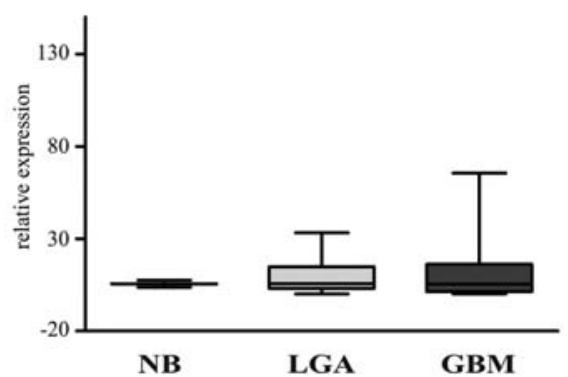

c)

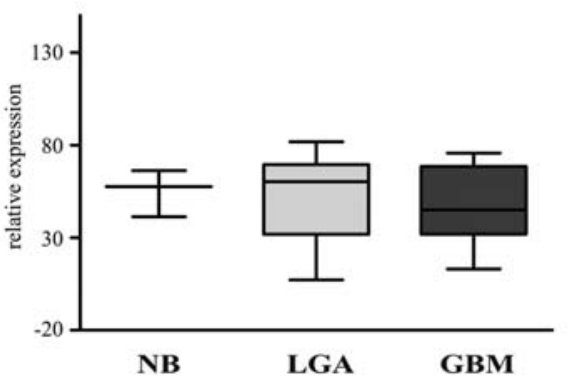

d)

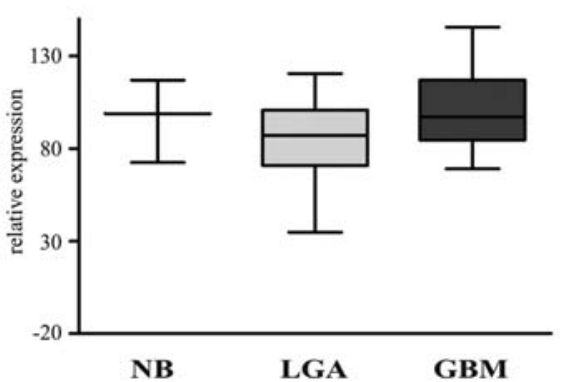

Figure 3. Expression analysis of RAF mRNA in NB and human astrocytic tumor samples by semiquantitative RT-PCR. (a) Total RNA from normal brain (NB), astrocytoma WHO grade II (LGA) and glioblastoma multiforme (GBM) tissue samples was used as template for RT-PCR analysis. Primers, specific for each transcript, were designed in flanking exons. cDNA from U251 cells was used as positive control (+). For negative control cDNA was excluded from the PCR reaction (-). The various cDNA concentrations were normalized to that of the housekeeping gene $\beta$-actin, which was used as internal loading control. The size (bp) of the A-RAF, B-RAF- C-RAF and B-actin cDNA fragment is indicated on the right. The numbers refer to the tumor samples used (33). (b) Box-plot analysis of densitometrically quantified A-RAF mRNA expression. Each value was normalized to the respective $\beta$-actin mRNA. The black line within the boxes represents the median expression, boxes show the quartiles and bars indicate minimum and maximum values. (c) Box-plot analysis of densitometrically quantified B-RAF mRNA expression. (d) Box-plot analysis of densitometrically quantified C-RAF mRNA expression.

of LGA to $33 \%$ of the GBM (Fig. 6a). A-RAF mRNA expression showed highest fluctuations. All NB samples had weak A-RAF expression, but in $7 \%$ of LGA and $20 \%$ of GBM there was no A-RAF mRNA detectable. In addition, $7 \%$ of GBM displayed strong A-RAF mRNA expression (Fig. 6a). Our analysis did not reveal any significant influence of gender, treatment regimen, recurrent vs. primary tumor or the location of the tumor on RAF expression levels.

Concentrations of RAF-proteins are regularly increased in human astrocytic tumors. Since the mRNA expression does not necessarily have to be correlated with protein expression $(33,40)$, we were anxious to confirm our RT-PCR data by Western blotting. Therefore, we optimized the antibodies using total cell-lysates of human glioblastoma cell lines U87, U251, U343, U373 and GaMG (Fig. 4). In all these cell lines the three RAF isoforms were detectable (Fig. 4a), however they were expressed in different concentrations (Fig. 4b). Whereas U87 displayed weakest A-RAF expression, followed by $\mathrm{U} 251$, the other cell lines tested expressed this RAF protein nearly equally (Fig. 4). It is known that there are several B-RAF splice variants detectable (44-46). We checked for 
a)

\section{U87 U251 U343 U373 GaMG}

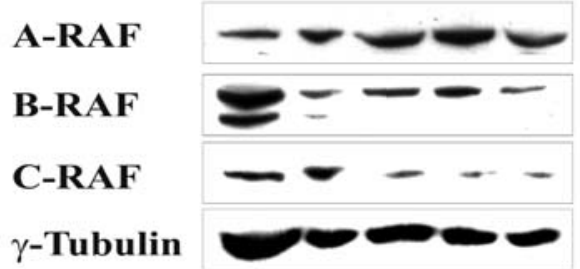

b)

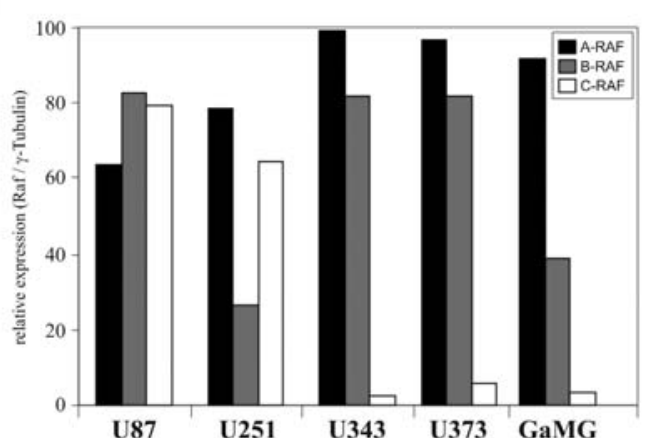

Figure 4. Western blot analysis of RAF protein expression by human glioblastoma cell lines U87, U251, U343, U373 and GaMG. (a) Protein lysates were isolated from the cells and separated by polyacrylamide gel electrophoresis. Expressed RAF proteins were visualized using specific antibodies. (b) Comparison of densitometrically quantified RAF protein expression in human glioblastoma cell lines. Each value was normalized to the respective $\gamma$-tubulin protein. expression of the 95 and the $68 \mathrm{kDa}$ splice variant of B-RAF in the glioblastoma cell-lines. Both forms were strongly expressed by U87 cells and weakly by U251 cells (Fig. 4a). In U343, U373 and GaMG, however, clear expression only of the $95 \mathrm{kDa}$ splice variant was detectable, whereas there was no expression of the $68 \mathrm{kDa}$ form (Fig. 4a). Therefore, the $68 \mathrm{kDa}$ form was excluded from the densitometric analysis and only the expression strength of $95 \mathrm{kDa} \mathrm{B}-\mathrm{RAF}$ is shown in Fig. 4b. C-RAF was strongly expressed by U87 and U251 cells, but weakly by U343, U373 and GaMG (Fig. 4).

These results encouraged us to perform Western blot analysis with total protein lysates of the same tumor samples used for the RT-PCR screening to detect RAF protein expression in the tissue. We found a clear increase of both, overall protein expression and number of tumor samples expressing A-RAF, $95 \mathrm{kDa} \mathrm{B}-\mathrm{RAF}$ and C-RAF concomitant with increasing WHO grading of the tumor (Figs. 5 and $6 \mathrm{~b}$ ). The high diversity of RAF expression between different tumors, already observed on mRNA level, was even more profound on protein level (Figs. 5 and 6b). Interestingly, A-RAF was detectable as a double band of equal strength in the tumor samples (Fig. 5a). It was only very weakly expressed by NB (Fig. 5a and b). Several LGA and GBM showed A-RAF expression with a clear increase in expression strength in GBM (Fig. 5a and b and Fig. 6b). Whereas the 95-kDa splice variant of B-RAF was clearly detectable in $\mathrm{NB}$, increased in its expression strength in LGA and was even more elevated in GBM (Figs. 5c and 6b), the 68-kDa

a)

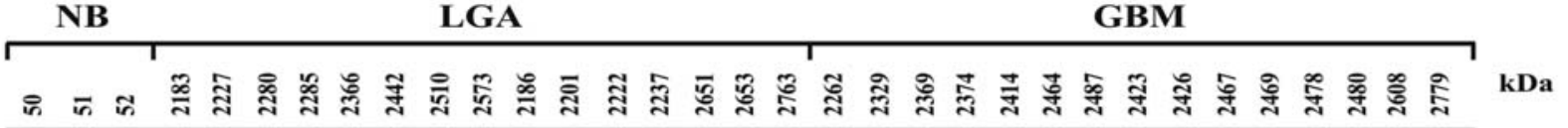

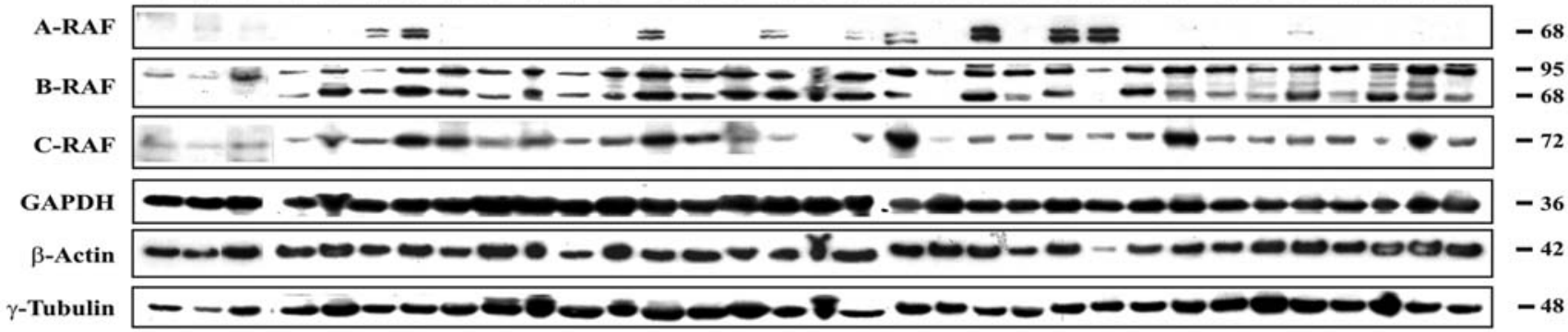

b)

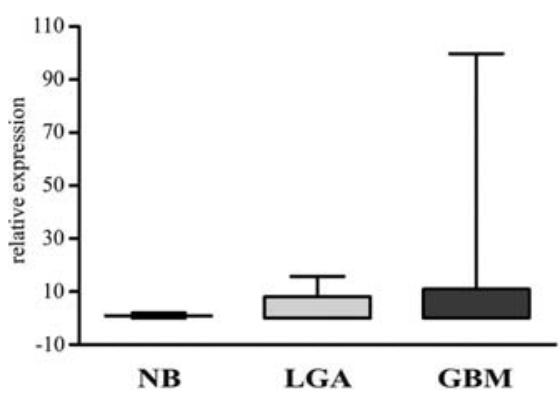

c)

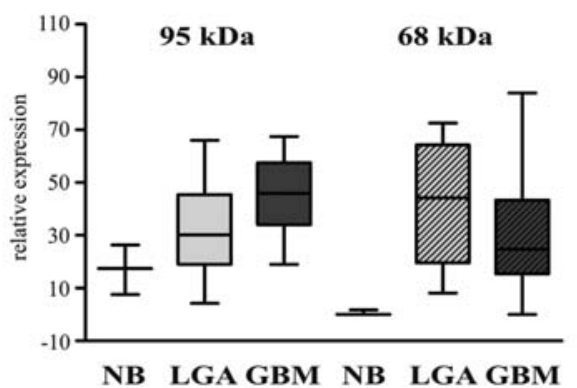

d)

\section{C-RAF}

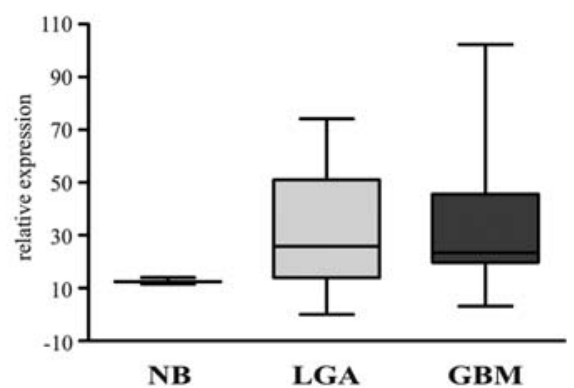

Figure 5. Western blot analysis of RAF protein expression by normal brain and human astrocytic tumor samples. (a) Protein lysates were isolated from NB, LGA and GBM samples and separated by polyacrylamide gel electrophoresis. Expressed RAF protein was visualized using specific antibodies. The numbers refer to the tumor samples used (33). (b) Box-plot analysis of densitometrically quantified A-RAF protein expression. Each value was normalized to the respective $\beta$-actin and $\gamma$-tubulin protein. The black line within the boxes represents the median expression, boxes show the quartiles and bars indicate minimum and maximum values. (c) Box-plot analysis of densitometrically quantified B-RAF protein expression. Two splice variants of 95 and 68 kDa, respectively, were detectable in the Western blots. (d) Box-plot analysis of densitometrically quantified C-RAF protein expression. 
a)

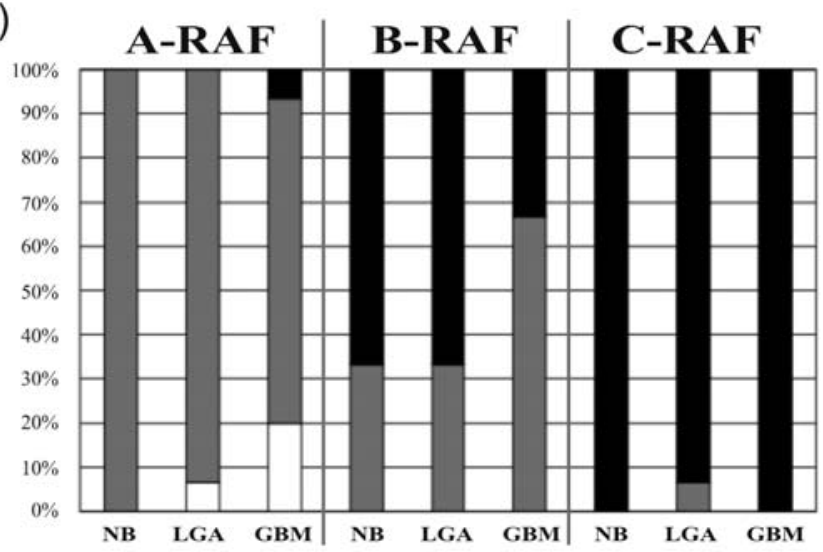

b)

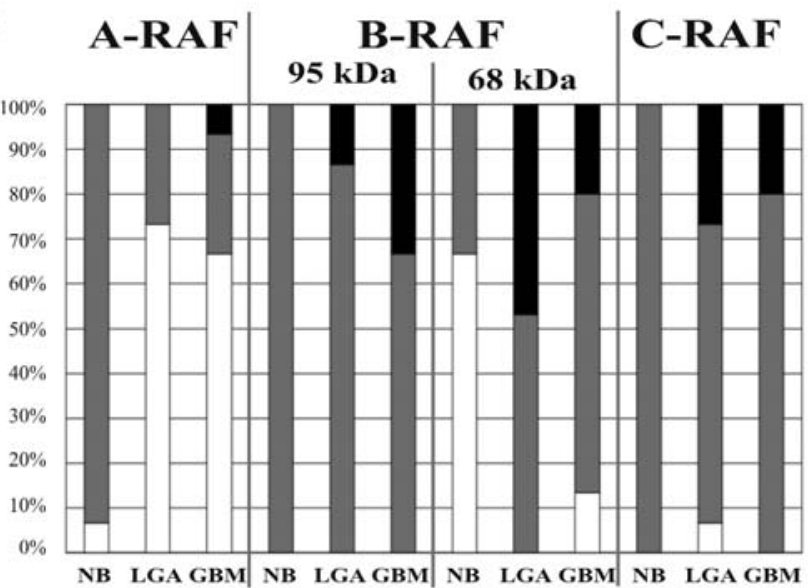

Figure 6. Percentage of tissue samples expressing RAF mRNA and protein, respectively. (a) Expression of A-RAF, B-RAF and C-RAF mRNA by NB, LGA and GBM. White columns represent samples with no detectable amounts of mRNA, light grey shows weak expression [ $>0$ but $<50$ on a scale from 0 (no expression detectable) to 100 (strongest expression of C-RAF, tumor 2329)] and black represents strong expression ( $\geq 50)$. (b) Expression of A-RAF, B-RAF and C-RAF protein by NB, LGA and GBM. White columns represent samples with no detectable amounts of RAF protein, light grey shows weak expression $[>0$ but $<50$ on a scale from 0 (no expression detectable) to 100 (strongest expression of GAPDH, tumor 2651)] and black represents strong expression $(\geq 50)$.

B-RAF form was absent in NB, then strongly appeared in LGA and was slightly reduced in its average relative expression in GBM (Fig. 5a and c and Fig. 6b). C-RAF was overexpressed by glioma tissue compared to NB (Fig. 5a and d), but not much altered in GBM when compared to LGA. However, variation of average relative expression was increased in GBM (Fig. 5a and d).

Expression of RAF-proteins in paraffin-embedded GBM sections. Western blotting shows that the three RAF isoforms A-RAF, B-RAF and C-RAF are expressed by human astrocytic tumor samples. However, they do not reveal which celltypes within the tumor section display expression. Therefore, we performed immunohistochemistry using paraffinembedded tissue sections derived from a number of different GBMs. Tissue stained with appropriate isotype control antibodies served as negative control (Fig. 7d). Immunostaining clearly confirmed the expression of the three RAF isoforms in tumor tissue (Fig. 7). A-RAF was expressed throughout the tumor tissue. The cytoplasm of nearly every tumor cell was stained (Fig. 7a). B-RAF showed a very similar expression throughout the tumor section in the cytoplasm of individual, large tumor cells (Fig. 7b). C-RAF staining, in contrast, showed highest concentrations in the endothelial cells around blood vessels, but there were also some tumor cells strongly stained and some blood vessels without signal (Fig. 7c).

Influence of RAF expression on patient's prognosis. Western blot analysis showed a high diversity of RAF expression between different tumors (Fig. 5a). Therefore, we were interested, whether RAF expression is correlated with the patient's median survival (Table III). Strong expression of A-RAF mRNA correlated with a reduction in the median survival by 43.1 weeks. However, A-RAF protein expression had only a marginal effect (Table III). In contrast, B-RAF mRNA expression and the expression of the $68-\mathrm{kDa}$ splice variant of the B-RAF protein correlated with increased median survival by 66.8 and 80.5 weeks, respectively (Table III). The 95-kDa form of B-RAF had only a marginal, but also positive effect. C-RAF protein expression in turn was negatively correlated with the patient's prognosis, since the median survival was reduced by 10.7 weeks (Table III). It was not possible to perform survival studies for C-RAF mRNA expression, because it was strongly expressed by nearly all patients (Fig. 3a).

A-RAF overexpression or knock-down does not influence tumor cell migration and proliferation. Since increase of A-RAF expression on mRNA and protein level was seen concomitantly with increasing WHO grading of the glioma (Figs. 3 and 5) and since A-RAF mRNA expression was negatively correlated with patients survival (Table III), we were interested to investigate, whether A-RAF expression does influence the migration behavior or proliferation rate of GBM cells. We transfected U251 cells with pCMV5 empty vector, pCMV5-A-RAF for transient A-RAF overexpression, scrambled siRNA and siRNA for a specific A-RAF knockdown (Fig. 8a). Spheroids for a migration assay were generated from these cells and the distance of cells spreading out from the spheroid was documented $0,12,24,36$ and $46 \mathrm{~h}$ after placing the spheroid (Fig. $8 \mathrm{~b}$ and Table IV).

In addition, 50,000 of the transfected cells were seeded onto $60 \mathrm{~mm}$ plates for a proliferation assay and increase of cell number was counted over a period of seven days (Fig. 8c and Table V). Western blotting of these proliferating cells showed transient A-RAF overexpression at day two, which then quickly diminished to normal level starting at day three (Fig. 8d). siRNA mediated A-RAF knock-down lasted for more then 4 days and started to diminish at day 6 (Fig. 8d). In both, the migration and the proliferation assay, there was no statistically significant difference between cells expressing normal, increased or decreased concentrations of A-RAF protein.

\section{Discussion}

Human primary glioblastomas are characterized by amplification ( $>40 \%$ of cases) or overexpression ( $>60 \%$ of cases) 

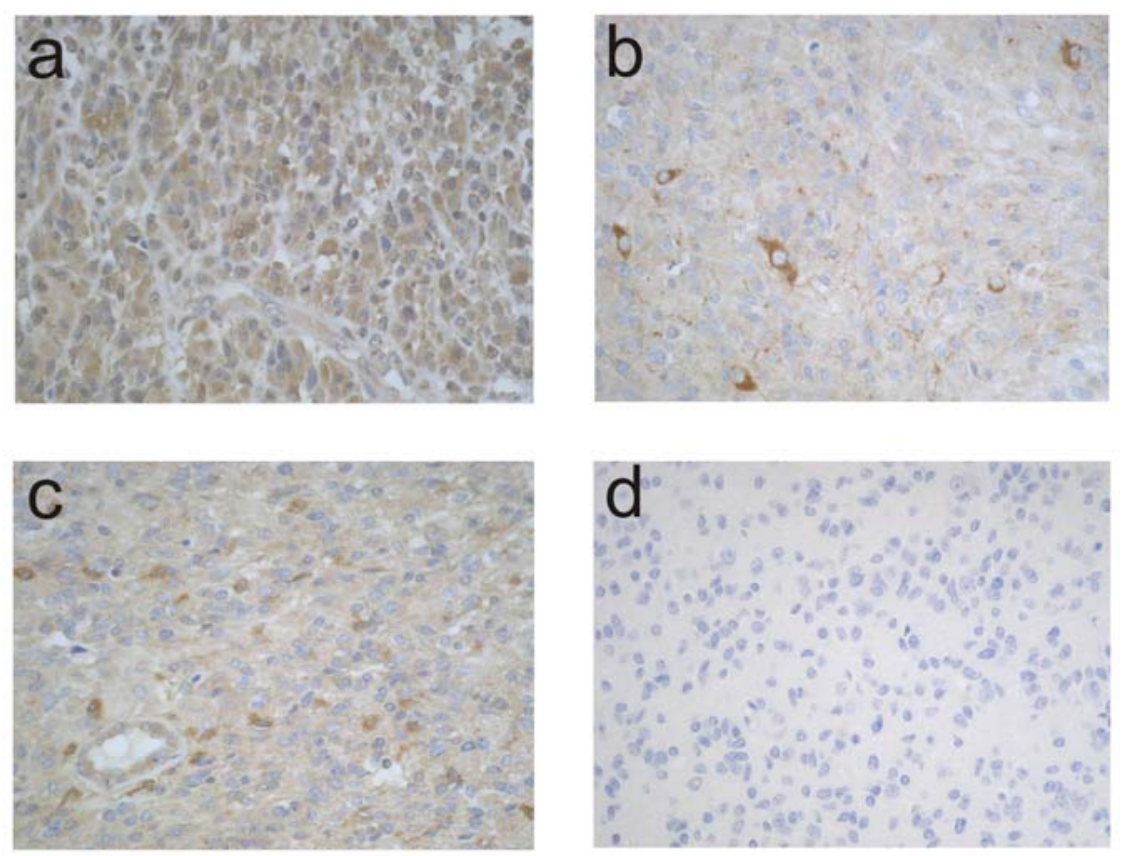

Figure 7. RAF expression on paraffin-embedded sections of a representative glioblastoma sample. (a-c) RAF expression (brown signal) was visualized by staining with specific antibodies. (a) A-RAF expression was detected in the cytoplasm of nearly all tumor sells throughout the section. (b) Expression of B-RAF by several large tumor cells throughout the section. (c) C-RAF was specifically found in the cytoplasm of endothelial cells around blood vessels but also in several tumor cells. (d) Tissue stained with appropriate isotype control antibodies served as negative control. All slides were magnified x40.

a)

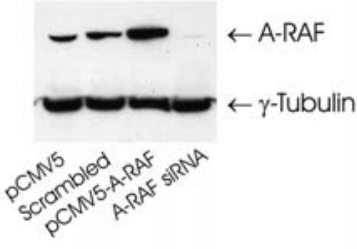

b)

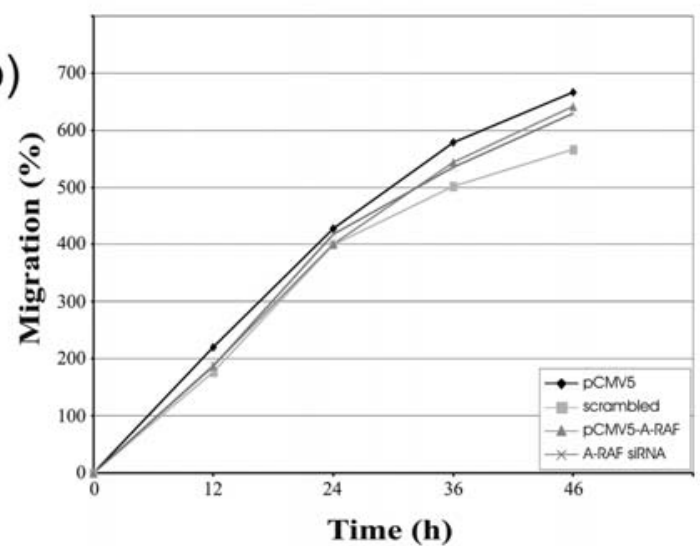

c)

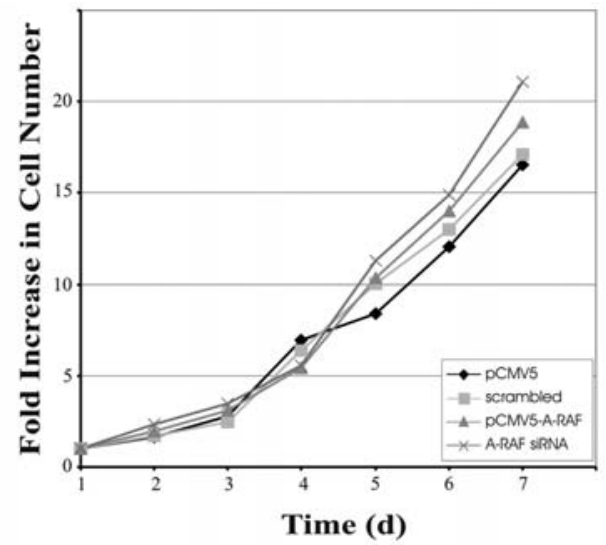

d)

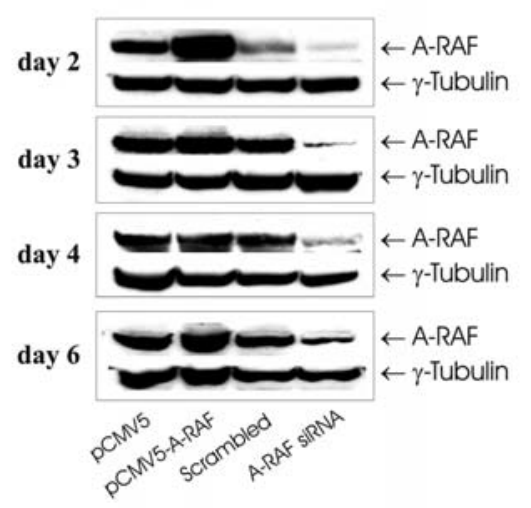

Figure 8. Effect of transient overexpression and siRNA knock-down of A-RAF in cultured U251 glioblastoma cells on their migration behavior and proliferation rate. (a) Western blot analysis of A-RAF overexpression and knock-down. Cells have been transfected with $2 \mu \mathrm{g}$ pCMV 5 empty vector as control, $2 \mu \mathrm{g}$ plasmid pCMV5-A-RAF for A-RAF overexpression, $3 \mu \mathrm{g}$ control siRNA scrambled and $3 \mu \mathrm{g}$ A-RAF specific siRNA, respectively. $\gamma$-tubulin served as loading control to ensure that equal protein concentrations have been loaded onto the gel. Shown is the effect $72 \mathrm{~h}$ after transfection. (b) Migration of U251 cells. Spheroids of this cell-line have been planted onto poly-L-lysine coated plates. The distance between cells migrating away from the spheroid and the border of the original spheroid has been measured at the indicated time-points. Error-bars have been excluded from the figure for clarity reasons. However, the standard errors of the mean (SE) are given in Table IV. (c) Proliferation of U251 cells. 50,000 transfected cells have been plated at day 0 onto 60-mm plates. Over a period of seven days cells have been trypsinized and counted each day. Error-bars have been excluded from the figure for clarity reasons. However, the standard errors of the mean (SE) are given in Table V. (d) After counting, cells have been lysed and analysed for A-RAF overexpression and knock-down, respectively, by Western blotting. 
Table IV. Migration from the edge of the spheroid (\%).

\begin{tabular}{lccccc}
\hline & \multicolumn{5}{c}{$\bar{X} \pm \mathrm{SE}$} \\
\cline { 2 - 6 } & $12 \mathrm{~h}$ & $24 \mathrm{~h}$ & $36 \mathrm{~h}$ & $46 \mathrm{~h}$ & $\mathrm{n}$ \\
\hline pCMV5 & $229 \pm 27$ & $428 \pm 47$ & $578 \pm 71$ & $667 \pm 87$ & 5 \\
pCMV5-A-RAF & $188 \pm 11$ & $400 \pm 24$ & $544 \pm 31$ & $642 \pm 33$ & 7 \\
Scrambled & $177 \pm 19$ & $400 \pm 42$ & $502 \pm 62$ & $567 \pm 71$ & 7 \\
A-RAF siRNA & $187 \pm 15$ & $418 \pm 29$ & $535 \pm 41$ & $630 \pm 52$ & 9 \\
\hline
\end{tabular}

$\mathrm{n}$, number of spheroids analysed independently.

of the epidermal growth factor receptor (EGFR) gene (6). The most common mutation associated with EGFR amplification is a large in-frame deletion of the cellular domain (EGFRvIII), which turns this receptor constitutively active $(47,48)$. Such EGFR overexpression and activation is positively correlated with GBM malignancy (6).

The classical signalling cascade activated by EGFR is the mitogenic Ras-RAF-MEK-ERK pathway, which is involved in regulation of a wide range of cellular functions (16-18). Receptor activation leads to activation of Ras protein familymembers, a group of small G-proteins (49). It has been shown that $\sim 30 \%$ of human tumors contain activating mutations in one of the three Ras genes $K$-ras, $N$-ras and $H$-ras $(24,50)$. Although the majority of GBM display elevated levels of Ras-GTP (13), and although overexpression of H-Ras can induce GBM formation in mouse models $(14,15)$, activating mutations in ras genes are very rare or absent in malignant gliomas $(29,32,51)$.

Therefore, we concentrated in our analysis on members of the protein serine/threonine kinase family activated by Ras proteins A-RAF, B-RAF and C-RAF, a family of well known oncoproteins. However, data on their role in development of human astrocytic gliomas are limited.

We analysed the mutational status of A-RAF and B-RAF in human GBM. Then we checked for RAF gene amplification by dot blot hybridization and analysed RAF mRNA and protein expression in three NB, 15 LGA and 15 GBM biopsies. The results from the expression analysis were correlated with patients prognosis. Finally, we performed functional assays to address a putative function of A-RAF in glioma cell proliferation and migration.

Miscellaneous alterations in exons 11 and 15 of B-RAF have been found in melanomas and in ovarian, thyroid and colorectal carcinomas (23). Most prominent was the T1799A (B-RAF V600E) exchange, accounting for $80 \%$ of the mutations found (23). Although this exchange also was detected in $11 \%$ (4 of 38) glioma cell lines, no mutations were found in 15 primary gliomas (23). However, in our screen of 44 GBM biopsies we detected one case with a heterozygous, tumor specific T1799A mutation, leading to the activating amino acid exchange V600E (Fig. 1b). No mutations were found in exon 11 of 74 analysed GBM samples (Table II). Therefore, $2 \%$ of GBM patients contained oncogenically activated B-RAF proteins in their tumors. This percentage is in accordance with findings of other groups. One study describes two T1799A mutations among 94 GBM (2\%) (29) and another reports two of the same alterations in 34 GBM (6\%) (30). This means that in total $3 \%$ (5 of 187) of all GBM contain activating B-RAF mutations, a small percentage in comparison to other malignancies.

A-RAF has not been analysed for mutations in GBM, yet. Therefore, we screened 66 GBM samples for mutations in exons corresponding to the mutationally most affected $B$-raf exons (Table II). We did not find any sequence alterations, except for one silent polymorphism in exon 10 of A-raf, leading to a C1001T exchange (Fig. 1a). The same genetic variant has been described in one case in a screen of 130 primary colorectal tumors for A-raf mutations (43). In this screen and in another, addressing $A$-raf sequence alterations in ovarian epithelial tumors, colorectal carcinomas, gastric adenocarcinomas and acute leukemias, no A-raf mutations were detected (20).

For C-RAF no mutations have been found either (43). The reason may be that both proteins may require multiple mutations for oncogenic activation, whereas B-RAF can be activated by a single base change, like e.g., T1799A (21). In addition, even certain tumor-associated inactivating B-RAF mutations have been shown to activate the mitogenic signalling pathway by heterodimerization of B-RAF with wild-type C-RAF (52-54), indicating that more than just one RAF family member may be necessary for oncogenic transformation. However, although the mitogenic signalling cascade plays a pivotal role during development of human gliomas, mutations of raf genes are a rare event in GBM. Therefore,

Table V. Fold increase in cell number.

\begin{tabular}{|c|c|c|c|c|c|c|c|}
\hline & \multicolumn{7}{|c|}{$\bar{X} \pm \mathrm{SE}$} \\
\hline & Day 1 & Day 2 & Day 3 & Day 4 & Day 5 & Day 6 & Day 7 \\
\hline pCMV5 & 1 & $1.67 \pm 0.13$ & $2.75 \pm 0.15$ & $6.95 \pm 0.38$ & $8.42 \pm 0.39$ & $12.03 \pm 0.32$ & $16.55 \pm 0.90$ \\
\hline pCMV5-A-RAF & 1 & $1.96 \pm 0.22$ & $3.09 \pm 0.22$ & $5.44 \pm 0.24$ & $10.33 \pm 0.57$ & $14.04 \pm 0.96$ & $18.87 \pm 1.10$ \\
\hline Scrambled & 1 & $1.70 \pm 0.05$ & $2.44 \pm 0.22$ & $6.40 \pm 0.34$ & $10.02 \pm 0.48$ & $12.98 \pm 0.67$ & $17.12 \pm 1.23$ \\
\hline A-RAF siRNA & 1 & $2.32 \pm 0.14$ & $3.45 \pm 0.37$ & $5.53 \pm 0.20$ & $11.29 \pm 0.29$ & $14.87 \pm 1.31$ & $21.97 \pm 1.08$ \\
\hline
\end{tabular}


we checked for other alterations leading to changes in RAF expression.

Dot blot hybridization suggested amplification of the A-raf gene in at least one out of 15 LGA and one out of 15 GBM (Fig. 2). Astrocytic tumors display a high level of aneuploidy already in early stages (55-57). It is discussed that aneuploidy leads to an imbalance of the signalling network in tumor cells with loss of tumorsuppressor genes and overexpression of oncogenes (57-59). The A-raf gene is located on Xp11.2 (16), a chromosome often numerically altered in human gliomas. Recently, it has been shown that a high percentage of gliomas also shows gains in B-RAF gene copy number and that such changes may lead to higher B-RAF expression and signalling (32). In our dot blot assay we did not find such alterations. However, our methodology can detect chromosomal amplification, but is not sensitive enough to reveal gene copy gains. Conventional comparative genomic hybridization $(\mathrm{CGH})$ arrays would be necessary. B-RAF is encoded at 7p34 (16). Gain of this chromosome is the most common chromosomal abnormality in LGA, found in $>50 \%$ of cases and leads to the observed EGFR amplification (1). $B$-raf gene copy gains have also been observed in follicular thyroid adenoma and follicular thyroid carcinoma (60). The development of lung adenocarcinomas and retro-auricular lymphomas in mouse models is accompanied by very high expression of normal sized C-RAF mRNA and protein, compared to normal cells (61). Together, these findings suggest that overexpression of RAF proteins may participate in the tumorigenic process. Indeed, we saw increased levels of A-RAF mRNA and protein expression in the two tumors with A-RAF amplification, whereas they did not display a major change in the expression strength of B-RAF or C-RAF.

Semiquantitative RT-PCR analysis of 15 LGA, 15 GBM and three normal brain (NB) samples revealed B-RAF and C-RAF mRNA expression homogeneously in nearly all samples analysed (Fig. 3a). Only A-RAF was not demonstrable in some LGA and GBM samples and displayed a high diversity in expression strength between the different glioma samples. Densitrometric analysis confirmed the diverse expression and showed a successive increase of A-RAF mRNA expression from NB via LGA to GBM (Fig. 3b). Recently, we showed that our methodology is sufficient to detect alterations in mRNA expression if astrocytic tumors of different WHO grade are compared with each other $(33,62)$.

More important than mRNA expression is the presence of functional protein in the tumor cell. Already in 1989 expression of C-RAF has been analysed in 18 different GBM cell lines by Northern blot hybridization. All cell lines tested expressed mRNA of this protein (63). Here, we confirmed these data by Western blotting of total lysates from U87, U251, U343, U373 and GaMG cells and also included analysis of A-RAF and B-RAF expression (Fig. 4). We found that all tested cell lines expressed the three RAF isoforms, but that expression strength differed between the different cell lines (Fig. 4b). This is in correspondence with findings of others who in addition screened THR, D54MG, T98G, D645MG, D423 and D566MG GBM cell lines positivly for RAF protein expression (28).

Looking at our tumor biopsy panel by Western blotting, the individually diverse RAF expression was even more profound on protein level than on mRNA level and also the differences between NB, LGA and GBM were more impressive (Fig. 5). A-RAF was only very weakly expressed by NB and increased noticeably via LGA to GBM. Interestingly, A-RAF was detectable as a doublet of equal strength in the tumor samples (Fig. 5a). Although two splice variants, resulting in truncated A-RAF proteins of $21 \mathrm{kDa}$ (DA-RAF1) and $17 \mathrm{kDa}$ (DA-RAF2), are known (64), our double bands were too large $(68 \mathrm{kDa})$ to correspond with them. In addition, the antibodies used for detection were directed against C-terminal epitopes not present in the splice variants. Therefore, we do not have data concerning expression of DA-RAF in astrocytic tumors. Yureyev et al also observed an A-RAF double band when they analysed A-RAF localization in mitochondria of cells from rat liver by Western blotting (65). They were not able to resolve the nature of distinction between the double bands and suggested posttranslational protein modification by phosphorylation or proteolytic peptide removal (65). Such alterations of A-RAF protein also may occur in brain tumor cells.

More then 10 different splice variants are known for B-RAF in a range from 67 to $99 \mathrm{kDa}(45,46)$. In neuronal tissues like spinal cord and brain the longer splice variants predominate (45). Here, we checked for expression of 95 and $68 \mathrm{kDa} \mathrm{B}-$ RAF in our panel of human gliomas. Whereas $68 \mathrm{kDa} \mathrm{B}-$ RAF was absent in NB, then strongly appeared in LGA and was slightly reduced again in its average expression in GBM, the $95 \mathrm{kDa}$ band was clearly detectable in all samples analysed (Fig. 5). It showed a gradual increase in expression concomitantly with increasing WHO grading, as did C-RAF protein expression (Fig. 5).

Generally, we detected an increase of protein expression with rising WHO grade of the tumor for all three RAF isoforms. The impact of this RAF expression became obvious when we correlated it with patients survival. Although the sampling was too small for statistically significant results, tendencies are clear. Whereas expression of A-RAF and C-RAF mRNA and protein had a negative effect on patients survival, B-RAF expression was positively correlated with prognosis (Table III). Expression of the $68-\mathrm{kDa}$ splice variant of B-RAF extended the median survival by 80.5 weeks and the patient with a tumor-specific activating B-RAF V600E amino acid exchange (Fig. 1) survived with stable disease for 5 years, before he relapsed. In colorectal carcinomas and malignant melanomas similar observations have been made. All patients harbouring activating B-RAF mutations in their colon carcinomas survived without recurrence compared to only $75 \%$ of 5 year survival in B-RAF negative cancers (66), and melanoma patients with B-RAF mutations exhibited a median survival of 12 months compared to 5 months median survival of patients without B-RAF mutations (22). However, other authors neither observed a positive, nor a negative influence of activated B-RAF in malignant melanomas, but reported a negative effect in metastasis (67). The positive effect of B-RAF expression may be due to its high activity $(21,68)$. It has been shown that strong and sustained B-RAF signals will induce cell cycle arrest, differentiation and senescence of cells $(24,54,69-72)$. In addition, B-RAF V600E expression leads to synthesis and secretion of IGFBP7, which inhibits in an autocrine/paracrine loop the B-RAF-MEK-ERK 
signalling and thereby induces senescence and apoptosis (73).

Our analysis revealed that A-RAF and C-RAF expression exerts a negative effect on patient's prognosis (Table III). High grade human gliomas are characterized by increased proliferation and migration activities of the tumor cells. Therefore, the effect of transient RAF overexpression and RNAi mediated gene knock-down in GBM cell lines has been investigated for A-RAF by us (Fig. 8) and for C-RAF by others (31). None of these experiments was associated with any change, neither of proliferation rates, nor of migration behavior (Fig. 8) (31). However, siRNA mediated knockdown of C-RAF in human cerebral microvascular endothelial cells (HCMEC) led to a reduction of cell survival and significant inhibition of tube formation and therefore might be involved in neoangiogenesis (31). This view is supported by our finding of strong C-RAF expression in the endothelial cells around blood vessels (Fig. 7). However, there were also some tumor cells strongly stained (Fig. 7). C-RAF is able to induce transcription of the multidrug resistance gene $\mathrm{mdr}-1$ and its activation has been associated with multidrug resistance of tumor cells $(18,74,75)$. Therefore, C-RAF may exert two essential functions in GBM cells: it could protect tumor cells against chemotherapeutics and it might promote angiogenesis and thereby advance oxygene supply within the tumor.

Oxygene supply is essential for the metabolism of cells. In contrast to normal cells, tumor cells have adapted to hypoxic conditions by switching to anaerobic glycolysis (Warburg effect), which is characterized by high rates of glucose consumption and reduced rates of oxidative phosphorylation, causing high lactate production even in the presence of oxygene (76). Recently, we showed that A-RAF directly binds to the glycolytic enzyme pyruvate kinase M2 (M2-PK) (77), induces transition of the dimeric to the tetrameric active form of M2-PK and thereby favors glycolytic energy production and promotes cell transformation and tumorigenesis (77-79). Glioblastomas are hypoxic tumors (62) and although the role of A-RAF remains poorly defined and it is the RAF kinase with weakest activity (75), its link to regulation of tumor cell metabolism may be of importance in view of its negative effect on GBM patient's survival.

In conclusion, we showed that RAF proteins may play an important role during development of human malignant gliomas. Although raf mutations are a rare event in GBM, overexpression on mRNA and protein level was regularly found. RAF expression was correlated with the patient's prognosis. Most probably, B-RAF expression causes cell cycle arrest and senescence of cells $(24,54,70-72)$ and therefore exerts the observed positive effect for the patient's survival. In functional assays, A-RAF and C-RAF expression did not have any influence on proliferation or migration of GBM cells (Fig. 8) (31). Therefore, they might be important for other cellular processes. C-RAF for example positively regulates survival of and tube formation by endothelial cells and may promote angiogenesis (31). A-RAF might be involved in regulation of tumor cell metabolism $(77,78)$ and thereby support proliferation under hypoxic conditions. Therefore, specifically targeting RAF proteins might be a valuable treatment option (6). However, initially specific
RAF functions during tumorigenesis of malignant gliomas have to be elucidated.

\section{Acknowledgements}

We thank Reinhold Krug (MSZ) for sequencing and Thomas Freiman (Neurochirurgische Klinik, Neurozentrum, University-Hospital Freiburg im Breisgau, Germany) for normal brain control tissue. We are very grateful to Michaela Kapp (University of Würzburg, Department of Gynaecology and Obstetrics, Würzburg, Germany) for technical assistance. This project was supported by Interdisziplinäres Zentrum für Klinische Forschung der Universität Würzburg (C.H. and G.H.V.).

\section{References}

1. Reifenberger G and Collins VP: Pathology and molecular genetics of astrocytic gliomas. J Mol Med 82: 656-670, 2004

2. Pignatti F, van den Bent M, Curran D, Debruyne C, Sylvester R, Therasse P, Afra D, Cornu P, Bolla M, Vecht C and Karim AB: Prognostic factors for survival in adult patients with cerebral low-grade glioma. J Clin Oncol 20: 2076-2084, 2002.

3. Shaw E, Arusell R, Scheithauer B, O'Fallon J, O'Neill B, Dinapoli R, Nelson D, Earle J, Jones C, Cascino T, Nichols D, Ivnik R, Hellman R, Curran W and Abrams R: Prospective randomized trial of low-versus high-dose radiation therapy in adults with supratentorial low-grade glioma: initial report of a North Central Cancer Treatment Group/Radiation Therapy Oncology Group/Eastern Cooperative Oncology Group study. J Clin Oncol 20: 2267-2276, 2002.

4. Cavenee WK, Furnari FB, Nagane M, Huang H-JS, Newcomb EW, Bigner DD, Weller M, Berens ME, Plate KH, Israel MA, Noble MD and Kleihues P: Diffusely infiltrating astrocytomas. In: Pathology and Genetics of Tumors of the Nervous System. WHO Classification of Tumors. Kleihues P and Cavenee WK (eds.). IARC, Lyon, pp10-21, 2000.

5. Stupp R, Mason WP, van den Bent MJ, Weller M, Fisher B, Taphoorn MJ, Belanger K, Brandes AA, Marosi C, Bogdahn U, Curschmann J, Janzer RC, Ludwin SK, Gorlia T, Allgeier A, Lacombe D, Cairncross JG, Eisenhauer E, Mirimanoff RO, European Organisation for Research and Treatment of Cancer Brain Tumor and Radiotherapy Groups and National Cancer Institute of Canada Clinical Trials Group: Radiotherapy plus concomitant and adjuvant temozolomide for glioblastoma. $\mathrm{N}$ Engl J Med 352: 987-996, 2005.

6. Reardon DA and Wen PY: Therapeutic advances in the treatment of glioblastoma: rationale and potential role of targeted agents. Oncologist 11: 152-164, 2006.

7. Schrock E, Blume C, Meffert MC, du Manoir S, Bersch W, Kiessling M, Lozanowa T, Thiel G, Witkowski R, Ried T and Cremer T: Recurrent gain of chromosome arm $7 \mathrm{q}$ in low-grade astrocytic tumors studied by comparative genomic hybridization. Genes Chromosomes Cancer 15: 199-205, 1996.

8. Wessels PH, Twijnstra A, Kessels AG, Krijne-Kubat B, Theunissen PH, Ummelen MI, Ramaekers FC and Hopman AH: Gain of chromosome 7, as detected by in situ hybridization, strongly correlates with shorter survival in astrocytoma grade 2 . Genes Chromosomes Cancer 33: 279-284, 2002

9. Kleihues P, Davis RL, Ohgaki H, Burger PC, Westphal M and Cavenee WK: Diffuse astrocytoma. In: Pathology and Genetics of Tumors of the Nervous System. World Health Organization Classification of Tumors. Kleihues P and Cavenee WK (eds.). IARC, Lyon, pp22-26, 2000.

10. Ichimura K, Bolin MB, Goike HM, Schmidt EE, Moshref A and Collins VP: Deregulation of the p14ARF/Mdm2/p53 pathway is a prerequisite for human astrocytic gliomas with G1-S transition control gene abnormalities. Cancer Res 60: 417-424, 2000.

11. Hermanson M, Funa K, Hartman M, Claesson-Welsh L, Heldin $\mathrm{CH}$, Westermark B and Nister M: Platelet-derived growth factor and its receptors in human glioma tissue: expression of messenger RNA and protein suggests the presence of autocrine and paracrine loops. Cancer Res 52: 3213-3219, 1992. 
12. Guha A, Dashner K, Black PM, Wagner JA and Stiles CD: Expression of PDGF and PDGF receptors in human astrocytoma operation specimens supports the existence of an autocrine loop. Int J Cancer 60: 168-173, 1995.

13. Guha A, Feldkamp MM, Lau N, Boss G and Pawson A: Proliferation of human malignant astrocytomas is dependent on Ras activation. Oncogene 15: 2755-2765, 1997.

14. Holland EC, Celestino J, Dai C, Schaefer L, Sawaya RE and Fuller GN: Combined activation of Ras and Akt in neural progenitors induces glioblastoma formation in mice. Nat Genet 25: 55-57, 2000.

15. Ding H, Roncari L, Shannon P, Wu X, Lau N, Karaskova J, Gutmann DH, Squire JA, Nagy A and Guha A: Astrocyte specific expression of activated p21-ras results in malignant astrocytoma formation in a transgenic mouse model of human gliomas. Cancer Res 61: 3826-3836, 2001

16. Hagemann $\mathrm{C}$ and Rapp UR: Isotype-specific functions of Raf kinases. Exp Cell Res 253: 34-46, 1999.

17. Peyssonnaux $\mathrm{C}$ and Eychene A: The Raf/MEK/ERK pathway: new concepts of activation. Biol Cell 93: 53-62, 2001.

18. Beeram M, Patnaik A and Rowinsky EK: Raf: a strategic target for therapeutic development against cancer. J Clin Oncol 23 6771-6790, 2005.

19. Emuss V, Garnett M, Mason C and Marais R: Mutations of C-RAF are rare in human cancer because C-RAF has a low basal kinase activity with B-RAF. Cancer Res 65: 9719-9726, 2005 .

20. Lee JW, Soung YH, Kim SY, Park WS, Nam SW, Min WS Kim SH, Lee JY, Yoo NJ and Lee SH: Mutational analysis of the ARAF gene in human cancers. APMIS 113: 54-57, 2005

21. Dhomen N and Marais R: New insight into BRAF mutations in cancer. Curr Opin Genet Dev 17: 31-39, 2007.

22. Kumar R, Angelini S, Czene K, Sauroja I, Hahka-Kemppinen M, Pyrhönen S and Hemminki K: BRAF mutations in metastatic melanoma: a possible association with clinical outcome. Clin Cancer Res 9: 3362-3368, 2003.

23. Davies H, Bignell G, Cox C, Stephens P, Edkins S, Clegg S, Teague J, Woffendin H, Garnett MJ, Bottomley W, Davis N, Dicks E, Ewing R, Floyd Y, Gray K, Hall S, Hawes R, Hughes J, Kosmidou V, Menzies A, Mould C, Parker A, Stevens C, Watt S, Hooper S, Wilson R, Jayatilake H, Gusterson BA, Cooper C, Shipley J, Hargrave D, Pritchard-Jones K, Maitland N, Chenevix-Trench G, Riggins GJ, Bigner DD, Palmieri G, Cossu A, Flanagan A, Nicholson A, Ho JWC, Leung SY Yuen ST, Weber BL, Seigler HF, Darrow TL, Paterson H, Marais R, Marshall CJ, Wooster R, Stratton MR and Futreal PA Mutations of the BRAF gene in human cancer. Nature 417: 949-954, 2002

24. Mercer KE and Pritchard CA: Raf proteins and cancer: B-Raf is identified as a mutational target. Biochim Biophys Acta 1653: 25-40, 2003

25. Storm SM and Rapp UR: Oncogene activation: c-raf-1 gene mutations in experimental and naturally occurring tumors. Toxicol Lett 67: 201-210, 1993

26. Rapp UR, Fensterle J, Albert S and Götz R: Raf kinases in lung tumor development. Adv Enzyme Regul 43: 183-195, 2003.

27. Edwards LA, Verreault M, Thiessen B, Dragowska WH, Hu Y, Yeung JHF, Dedhar S and Bally MB: Combined inhibition of the phosphatidylinositol 3-kinase/Akt and Ras/mitogen-activated protein kinase pathways results in synergistic effects in glioblastoma cells. Mol Cancer Ther 5: 645-654, 2006.

28. Sathornsumetee S, Hjelmeland AB, Keir ST, McLendon RE, Batt D, Ramsey T, Yusuff N, Rasheed BKA, Kieran MW, Laforme A, Bigner DD, Friedman HS and Rich JN: AAL881, a novel small molecule inhibitor of RAF and vascular endothelial growth factor receptor activities, blocks the growth of malignant glioma. Cancer Res 66: 8722-8730, 2006.

29. Knobbe CB, Reifenberger J and Reifenberger G: Mutation analysis of the Ras pathway genes NRAS, HRAS, KRAS and BRAF in glioblastomas. Acta Neuropathol 108: 467-470, 2004.

30. Basto D, Trovisco V, Lopes JM, Martins A, Pardal F, Soares P and Reis RM: Mutation analysis of B-RAF gene in human gliomas. Acta Neuropathol 109: 207-210, 2005.

31. Culmsee C, Gasser E, Hansen S, Tonn J-C, Wagner E and Goldbrunner R: Effects of Raf-1 siRNA on human cerebral microvascular endothelial cells: a potential therapeutic strategy for inhibition of tumor angiogenesis. Brain Res 1125: 147-154, 2006
32. Jeuken J, van den Broecke C, Gijsen S, Boots-Sprenger S and Wesseling P: RAS/RAF pathway activation in gliomas: the result of copy number gains rather than activating mutations. Acta Neuropathol 114: 121-133, 2007.

33. Stojic J, Hagemann C, Haas S, Herbold C, Kühnel S, Gerngras S, Roggendorf W, Roosen K and Vince GH: Expression of matrix metalloproteinases MMP-1, MMP-11 and MMP-19 is correlated with the WHO-grading of human malignant gliomas. Neurosci Res 60: 40-49, 2008.

34. Kleihues P, Louis DN, Scheithauer BW, Rorke LB, Reifenberger G, Burger PC and Cavenee WK: The WHO classification of tumors of the nervous system. J Neuropathol Exp Neurol 61: 215-225, 2002.

35. Akslen LA, Andersen KJ and Bjerkvig R: Characteristics of human and rat glioma cells grown in a defined medium. Anticancer Res 8: 797-803, 1988.

36. Hagemann C, Meyer C, Stojic J, Eicker S, Gerngras S, Kühnel S, Roosen $\mathrm{K}$ and Vince GH: High efficiency transfection of glioma cell lines and primary cells for overexpression and RNAi experiments. J Neurosci Methods 156: 194-202, 2006.

37. Karasarides M, Chiloeches A, Hayward R, Niculescu-Duvaz D, Scanlon I, Friedlos F, Ogilvie L, Hedley D, Martin J, Marshall CJ, Springer CJ and Marais R: B-Raf is a therapeutic target in melanoma. Oncogene 23: 6292-6298, 2004.

38. MAFFT Version 6. Multiple alignment program for amino acid or nucleotide sequences [http://align.bmr.kyushu-u.ac.jp/ mafft/online/server/]

39. Boxshade 3.21. Pretty printing and shading of multiple alignment files [http://www.ch.embnet.org/software/BOX_ form.html]

40. Hagemann C, Stojic J, Gerngras S, Kühnel S, Said HM, Patel R, Kämmerer U, Vordermark D, Roosen K and Vince GH: Expression analysis of the autosomal recessive primary microcephaly genes MCPH1 (Microcephalin) and MCPH5 (ASPM, abnormal spindle-like, microcephaly associated) in human malignant gliomas. Oncol Rep 20: 301-308, 2008.

41. Primer 3 (v. 0.4.0) Pick primers from a DNA sequence [http://frodo.wi.mit.edu/cgi-bin/primer3/primer3_www.cgi]

42. Goldbrunner RH, Bouterfa H, Vince GH, Bernstein JJ, Roosen K and Tonn J-C: Transfection and dye premarking of human and rat glioma cell lines affects adhesion, migration and proliferation. Anticancer Res 17: 4467-4471, 1997.

43. Fransén K, Klintenäs M, Österström A, Dimberg J, Monstein H-J and Söderkvist P: Mutation analysis of the BRAF, ARAF and RAF-1 genes in human colorectal adenocarcinomas. Carcinogenesis 25: 527-533, 2004.

44. Eychène A, Barnier JV, Dezélée P, Marx M, Laugier D, Calogeraki I and Clothy G: Quail neuroretina c-Rmil (B-raf) proto-oncogene cDNAs encode two proteins of 93.5 and $95 \mathrm{kDa}$ resulting from alternative splicing. Oncogene 7: 1315-1323, 1992.

45. Barnier JV, Papin C, Eychène A, Lecoq O and Calothy G: The mouse B-raf gene encodes multiple protein isoforms with tissue-specific expression. J Biol Chem 270: 23381-23389, 1995.

46. Eychène A, Dusanter-Fourt I, Barnier JV, Papin C, Charon M, Gisselbrecht $\mathrm{S}$ and Calothy $\mathrm{G}$ : Expression and activation of $\mathrm{B}-$ Raf kinase isoforms in human and murine leukemia cell lines. Oncogene 10: 1159-1165, 1995.

47. Ekstrand AJ, Sugawa N, James CD and Collins VP: Amplified and rearranged epidermal growth factor receptor genes in human glioblastomas reveal deletions of sequences encoding portions of the N- and/or C-terminal tails. Proc Natl Acad Sci USA 89: 4309-4313, 1992 .

48. Ekstrand AJ, Longo N, Hamid ML, Olson JJ, Liu L, Collins VP and James CD: Functional characterization of an EGF receptor with a truncated extracellular domain expressed in glioblastomas with EGFR gene amplification. Oncogene 9: 2313-2320, 1994.

49. Zebisch A, Czernilofsky AP, Keri G, Smigelskaite J, Sill H and Troppmair J: Signaling through Ras-Raf-MEK-ERK: from basics to bedside. Curr Med Chem 14: 601-623, 2007.

50. Kiaris H and Spandidos DA: Mutations of ras gene in human tumours (review). Int J Oncol 7: 413-421, 1995.

51. Gömöri E, Dóczi T, Pajor L and Matolcsy A: Sporadic p53 mutations and absence of Ras mutations in glioblastomas. Acta Neurochir (Wien) 141: 593-599, 1999.

52. Wan PT, Garnett MJ, Roe SM, Lee S, Niculescu-Duvaz D, Good VM, Jones CM, Marshall CJ, Springer CJ, Barford D, Marais R and Cancer Genome Project: Mechanism of activation of the Raf-ERK signaling pathway by oncogenic mutations of B-Raf. Cell 116: 855-867, 2004 
53. Garnett MJ, Rana S, Paterson H, Barford D and Marais R: Wild-type and mutant B-Raf activate c-Raf through distinct machanisms involving heterodimerization. Mol Cell 20: 963-969, 2005.

54. Rapp UR, Götz R and Albert S: BuCy RAFs drive cells into MEK addiction. Cancer Cell 9: 9-12, 2006.

55. Cianculli AM, Morace E, Coletta AM, Occhipinti E, Gandolfo GM, Leorardo G and Carapella CM: Investigation of genetic alterations associated with development and adverse outcome in patients with astrocytic tumor. J Neurooncol 48 : 95-101, 2000.

56. Loeper S, Romeike BFM, Heckmann N, Jung V, Henn W, Feiden W, Zhang KD and Urbschat S: Frequent mitotic errors in tumor cells of genetically micro-heterogeneous glioblastomas. Cytogenet Cell Genet 94: 1-8, 2001.

57. Shapiro JR: Genetic alterations associated with adult diffuse astrocytic tumors. Am J Med Genet 115: 194-201, 2002.

58. Von Deimling A, Louis DN and Wiestler OD: Molecular pathways in the formation of gliomas. Glia 15: 328-338, 1995.

59. Duesberg P, Li R, Fabarius A and Hehlmann R: The chromosomal basis of cancer. Cell Oncol 27: 293-318, 2005.

60. Ciampi R, Knauf JA, Rabes HM, Fagin JA and Nikiforov YE: BRAF kinase activation via chromosomal rearrangement in radiation-induced and sporadic thyroid cancer. Cell Cycle 4: 547-548, 2005.

61. Rapp UR, Cleveland JL, Storm SM, Beck TW and Huleihel M: Transformation by Raf and myc oncogenes. In: Oncogenes and Cancer. Aaronson SA, et al (eds.) Japan Scl Soc Press, Tokyo/VNU Sci Press, Utrecht, pp53-74, 1987.

62. Said HM, Hagemann C, Staab A, Stojic J, Kühnel S, Vince GH, Flentje M, Roosen K and Vordermark D: Expression patterns of the hypoxia-related genes osteopontin, CA9, erythropoietin, VEGF and HIF-1 (in human glioma in vitro and in vivo. Radiother Oncol 83: 398-405, 2007.

63. LaRocca RV, Rosenblum M, Westermark B and Israel MA: Patterns of proto-oncogene expression in human glioma cell lines. J Neurosci Res 24: 97-106, 1989.

64. Yokoyama T, Takano K, Yoshida A, Katada F, Sun P, Takenawa T, Andoh T and Endo T: DA-Raf1, a competent intrinsic dominant-negative antagonist of the Ras-ERK pathway, is required for myogenic differentiation. J Cell Biol 177: 781-793, 2007.

65. Yureyev A, Ono M, Goff SA, Macaluso F and Wennogle LP: Isoform-specific localization of A-Raf in mitochondria. Mol Cell Biol 20: 4870-4878, 2000.

66. Yuen ST, Davies H, Chan TL, Ho, JW, Bignell GR, Cox C, Stephens P, Edkins S, Tsui WW, Chan AS, Futreal PA, Stratton MR, Wooster R and Leung SY: Similarity of the phenotypic patterns associated with BRAF and KRAS mutations in colorectal neoplasia. Cancer Res 62: 6451-6455, 2002.
67. Houben R, Becker JC, Kappel A, Terheyden P, Bröcker E-B, Goetz R and Rapp UR: Constitutive activation of the Ras-Raf signaling pathway in metastatic melanoma is associated with poor prognosis. J Carcinog 3: 6, 2004.

68. Hüser M, Luckett J, Chiloeches A, Mercer K, Iwobi M, Giblett S, Sun X-M, Brown J, Marais R and Pritchard C: MEK kinase activity is not necessary for Raf-1 function. EMBO J 20: 1940-1951, 2001

69. Woods D, Parry D, Cherwinski H, Bosch E, Lees E and McMahon M: Raf-induced proliferation or cell cycle arrest is determined by the level of Raf activity with arrest mediated by p21Cip1. Mol Cell Biol 17: 5598-5611, 1997.

70. Kerkhoff E and Rapp UR: High-intensity Raf signals convert mitotic cell cycling into cellular growth. Cancer Res 58: $1636-1640,1998$

71. Garnett MJ and Marais R: Guilty as charged: B-Raf is a human oncogene. Cancer Cell 6: 313-319, 2004.

72. Michaloglou C, Vredeveld LCW, Soengas MS, Denoyelle C, Kuilman T, van der Horst CMAM, Majoor DM, Shay JW, Mooi WJ and Peeper DS: BRAFE600-associated senescencelike cell cycle arrest of human naevi. Nature 436: 720-724, 2005.

73. Wajapeyee N, Serra RW, Zhu X, Mahalingam M and Green MR: Oncogenic BRAF induces senescence and apoptosis through pathways mediated by the secreted protein IGFBP7. Cell 132: 363-374, 2008

74. Cornwell MM and Smith DE: A signal transduction pathway for activation of the mdr1 promoter involves the proto-oncogene c-raf kinase. J Biol Chem 268: 15347-15350, 1993.

75. McCubrey JA, Steelman LS, Chappell WH, Abrams SL, Wong EWT, Chang F, Lehmann B, Terrian DM, Milella M, Tafuri A, Stivala F, Libra M, Basecke J, Evangelisti C, Martelli AM and Franklin RA: Roles of the Raf/MEK/ERK pathway in cell growth, malignant transformation and drug resistance. Biochim Biophys Acta 1773: 1263-1284, 2007.

76. Warburg O: On the origin of cancer cells. Science 123: 309-314, 1956.

77. Le Mellay V, Houben R, Troppmair J, Hagemann C, Mazurek S, Frey U, Beigel J, Weber C, Benz R, Eigenbrodt E and Rapp UR: Regulation of glycolysis by Raf protein serine/threonine kinases. Adv Enzyme Regul 42: 317-332, 2002.

78. Mazurek S, Drexler HC, Troppmair J, Eigenbrodt E and Rapp UR: Regulation of pyruvate kinase type M2 by A-Raf: a possible glycolytic stop or go mechanism. Anticancer Res 27: 3963-3971, 2007.

79. Christofk HR, Vander Heiden MG, Harris MH, Ramanathan A, Gerszten RE, Wei R, Fleming MD, Schreiber SL and Cantley LC: The M2 splice isoform of pyruvate kinase is important for cancer metabolism and tumour growth. Nature 452: 230-233, 2008. 